\title{
EXPANDING ACCESS TO POST-SECONDARY EDUCATION FOR YOUTH WITH PRECARIOUS LEGAL STATUS: A RYERSON UNIVERSITY CASE-STUDY
}

\author{
by \\ Dayana A. Gonzalez Mateus \\ BA, York University, 2016 \\ A Major Research Paper \\ presented to Ryerson University \\ in partial fulfillment of the requirements for the degree of \\ Master of Arts \\ in the Program of \\ Immigration and Settlement Studies
}

Toronto, Ontario, Canada, 2017

(C) Dayana A. Gonzalez Mateus 2017 


\section{AUTHOR'S DECLARATION FOR ELECTRONIC SUBMISSION OF A MAJOR RESEARCH PAPER (MRP)}

I hereby declare that I am the sole author of this Major Research Paper. This is a true copy of the MRP, including any required final revisions.

I authorize Ryerson University to lend this MRP to other institutions or individuals for the purpose of scholarly research

I further authorize Ryerson University to reproduce this MRP by photocopying or by other means, in total or in part, at the request of other institutions or individuals for the purpose of scholarly research.

I understand that my MRP may be made electronically available to the public.

Dayana A. Gonzalez Mateus 


\title{
EXPANDING ACCESS TO POST-SECONDARY EDUCATION FOR YOUTH WITH PRECARIOUS LEGAL STATUS: A RYERSON UNIVERSITY CASE-STUDY
}

\author{
(C) Dayana A. Gonzalez Mateus \\ Master of Arts 2017 \\ Immigration and Settlement Studies \\ Ryerson University
}

\begin{abstract}
Access to post-secondary education (PSE) for people with precarious legal status (PLS) is an understudied topic, particularly in the Canadian context, resulting in a substantial gap in the theoretical and practical understanding of the subject and a growing pool of wasted talent and deferred dreams. This paper explores the possibility of expanding access to PSE for students with PLS at Ryerson University, given the university's unique commitment to equity, diversity and inclusion and its intention to be a City Builder. I propose an initiative that would admit academically qualified students into Ryerson, and put in place a tuition equity policy that would honour students' residency in the province, thus waiving international fees. This paper is structured as a sort of "road-map" that could be utilized by other universities in Ontario interested in undertaking similar initiatives.
\end{abstract}

Key Words: Post-secondary Education; Precarious Legal Status; Tuition Equity Policy; Youth; Access to Education; Marginalized Group; Equity Diversity and Inclusion; Ryerson University 


\section{ACKNOWLEDGMENT}

This MRP and my academic journey could have not been completed without the support and generous assistance of several individuals. I am pleased to take this opportunity to express my sincere gratitude.

Thank you to Dr. Harald Bauder for his invaluable support and instruction throughout my work as his research assistant and the supervision on this project. Dr. Bauder's skilful balancing of frank criticism, constructive advice and encouragement was essential to help me sort out where I intended to go with this MRP. Thank you to Dr. Idil Atak, for enthusiastically agreeing to be my second reader, for having an open-door policy throughout the program, and for encouraging me to explore different ideas in her class.

To all my professors both at York and Ryerson University for going well beyond the call of duty to provide me with continuous support and invaluable knowledge; and for encouraging me to believe my ideas were worth considering, and more importantly, worth writing about.

I will forever be grateful for the friendships that were forged while completing this program, and for the wisdom and unforgettable moments the ISS crew provided me with.

Thank you to Agnes, Amy, Amanda, Erika and each and every one of my dear friends who have dedicated their time for years to edit my work. To Tanya Aberman and Paloma Villegas for all their insightful information, which was instrumental to the further development of this initiative.

My greatest debt is to my family. My madre (mother) and hermanos (brothers) Saul and Jay, who have been the one true constant and only superheroes in my life. There are no words to express the endless sacrifices my mother and older brother have made to ensure our future, instilling the value of labour and dignity in us. I hope you both know I aspire to be like you, and hope to make you proud each and every day. I dedicate this MRP and all my accomplishments to you. Los amo tanto, y siempre tengo presente todos los sacrificios de cuerpo y alma que han hecho por nosotros y espero algún día poder pagar con amor esta gran deuda.

Lastly, I want to thank my partner Camilo. Thank you for believing in me, caring for me and for always encouraging me to reach for the stars. This would not have been possible without your support. Te amo! 


\section{TABLE OF CONTENTS}

AUTHOR'S DECLARATION

ABSTRACT

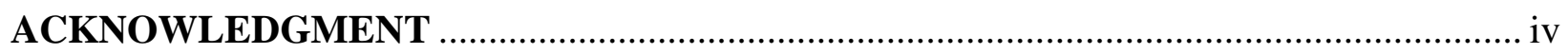

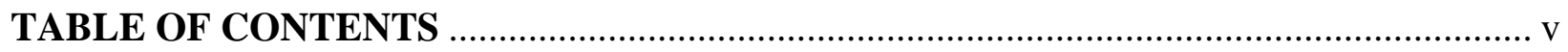

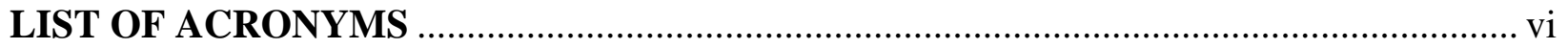

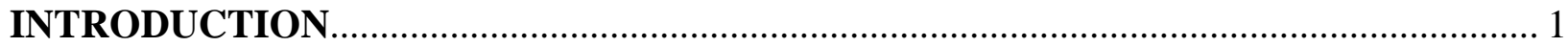

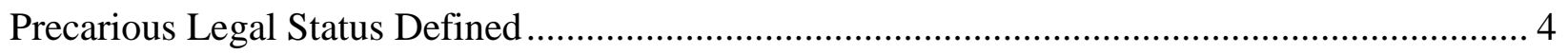

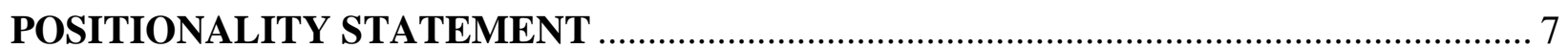

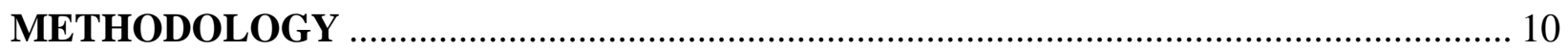

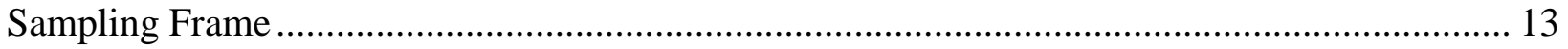

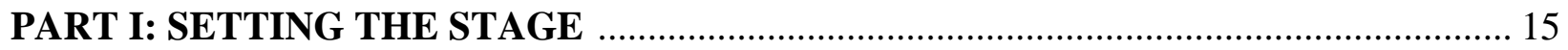

CH. 1 - THE LEGAL CONTRADICTIONS OF THE RIGHT TO EDUCATION ...................... 15

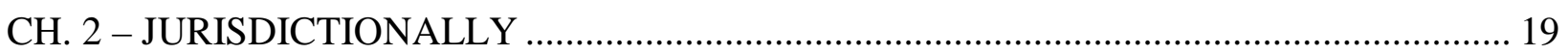

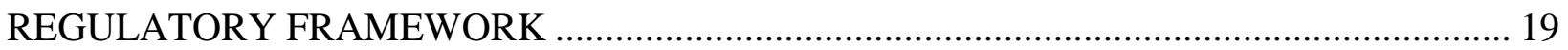

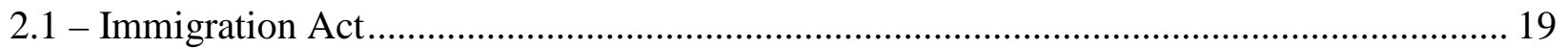

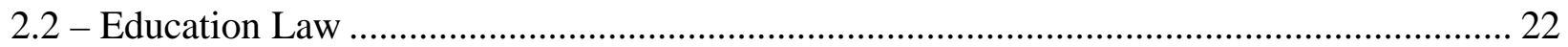

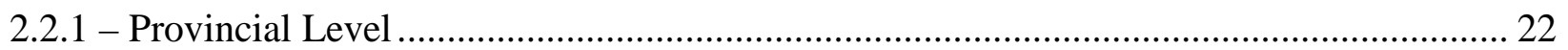

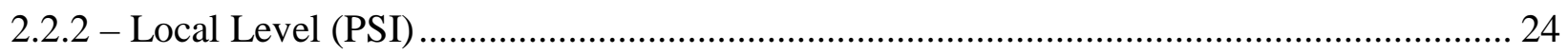

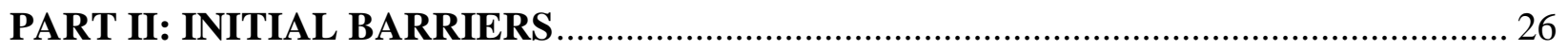

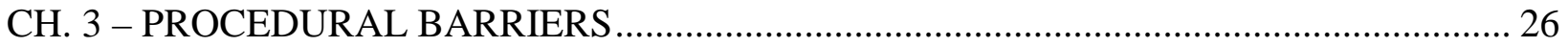

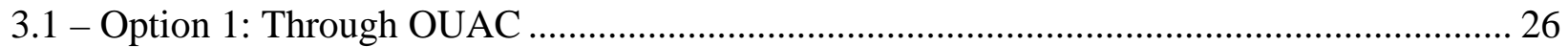

3.2 - Option 2: Apply Directly to Ryerson University ………………........................................ 29

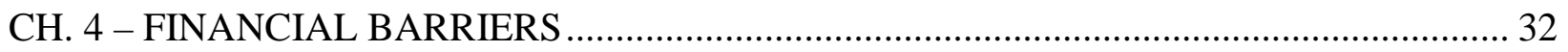

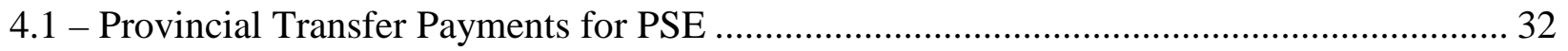

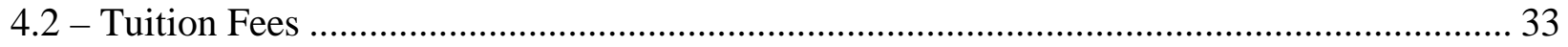

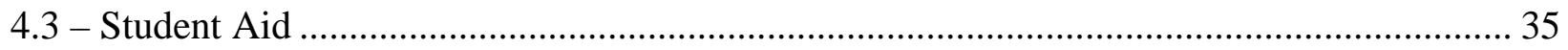

4.4 - University and Community Partnerships ……………........................................................... 36

PART III: ARGUMENTS FOR AND AGAINST THE EXPANSION OF ACCESS TO POST SECONDAY EDUCATION 
CH. 5 - REOCCURRING CONCERNS ...................................................................... 39

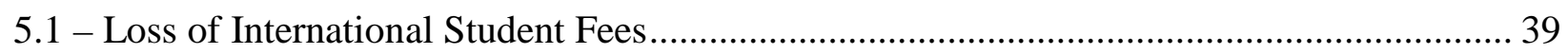

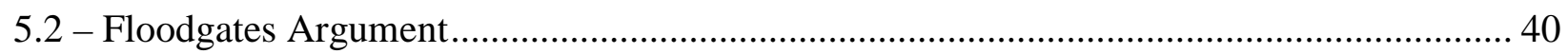

5.3 - Burden on Taxpayers and Denied Opportunities to Residents with Immigration Status .... 40

5.4 - Enhancing Accessibility to PSE Rewards "Illegality".................................................. 41

CH. 6 - ARGUMENTS ADVOCATING FOR EXPANDED ACCESS ................................. 43

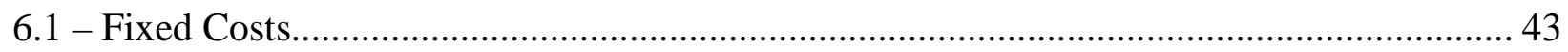

6.2 - Domestic Fees Should be Based on De-Facto Residency ............................................ 44

6.3 - Wasted Talent and Lost Opportunity for an Educated Workforce .................................. 44

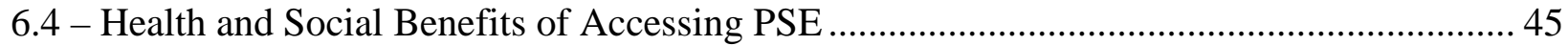

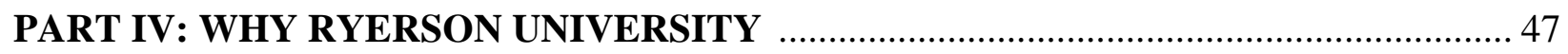

CH. 7 - RYERSON'S VISION FOR THE FUTURE AND COMMITMENT TO EDI............. 47

PART V: SUGGESTIONS FOR LAW AND POLICY REFORM ................................... 51

CH. 8 - STRATEGIES FOR REGULARIZATION ........................................................ 51

8.1 - Humanitarian \& Compassionate $(\mathrm{H} \& \mathrm{C})$ Application ................................................ 51

8.2 - Expansion of the eligibility criteria of current programs .................................................. 53

CH. 9 - SUGGESTIONS FOR A TUITION EQUITY POLICY AT THE PROVINCIAL

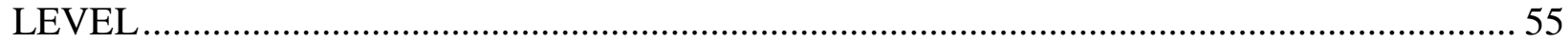

PART VI: SUMMARY OF RECOMMENDATIONS ............................................... 58

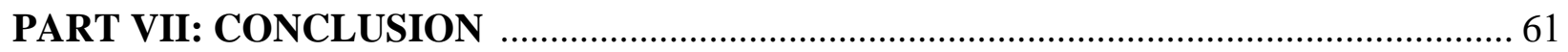

APPENDIX 1: Eligible criteria for the Ontario Universities Application Centre 1010 \& $105 \ldots 63$

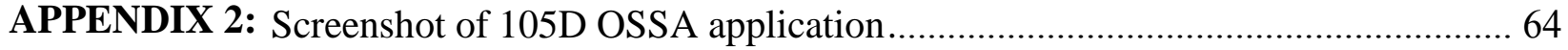

APPENDIX 3: Eligibility for the Ontario Student Assistance Program .......................................6 65

APPENDIX 4 : Eligibility criteria for Provincial Educational Transfers ............................... 66

APPENDIX 5: The Queen Mary University of London's eligibility criteria for the Asylum

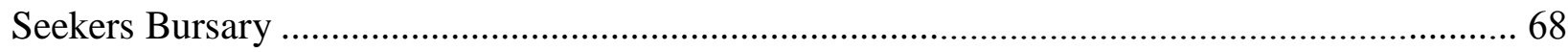

APPENDIX 6: State's eligibly criterial for in-state tuition fees in the United States ............... 69

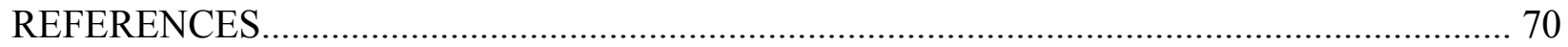




\section{LIST OF ACRONYMS}

EDI - Equity, Diversity and Inclusion

DADT - Don't Ask Don’t Tell

IRPA - Immigration and Refugee Protection Act

IRPR - Immigration and Refugee Protection Regulations

FIPPA - Freedom of Information and Protection of Privacy Act

MRP - Major Research Paper

OEA - Ontario Education Act

OEN - Ontario Education Number

OSAP - Ontario Student Assistance Program

OSSA - Ontario Secondary School Application

OUAC - Ontario Universities’ Application Centre

OPFDM - Ontario Operating Funds Distribution Manual

PLS - Precarious Legal Status

PSECE - Post-Secondary Education Choice and Excellence Act

PSE - Post-Secondary Education

PSI - Post-Secondary Institution

TDSB - Toronto District School Board

SIN - Social Insurance Number 


\section{INTRODUCTION}

The exact number of people with precarious legal status (PLS) in Canada is unknown, and estimates range drastically depending on the source. However, this does not diminish the importance of advocating alongside this marginalized population to ensure the recognition of their human rights, and access to social services. One of the ongoing advocacy battles this Major Research Paper (MRP) will address is the lack of sustainable pathways for post-secondary education (PSE) for people with PLS.

Access to PSE for people with PLS is an understudied topic, particularly in the Canadian context, resulting in a substantial gap in the theoretical and practical understanding of the subject. Decades of grassroots advocacy campaigns in Canada have led to the recognition of the right to compulsory education of children and youth, regardless of immigration status. These advocacy victories have eventually materialised in legislative changes at the provincial level, and local policies such as the "Don't Ask Don't Tell," (DADT) by the Toronto District School Board (TDSB).

Although efforts have been slow, administrative practices are inconsistently applied, and obstacles remain, we must concede that these policy changes have created pathways for students with PLS to obtain a high school diploma. Nonetheless, the acknowledgment of the right to education has not been extended at the post-secondary level, which has resulted in restricted access for people with PLS. Individuals who without a permanent immigration designation face substantial legal and financial barriers that more often than not are too great to be overcome.

Though I acknowledge that sustainable pathways to PSE must be expanded to all people with PLS, I find that the unique (temporary) integration of youth who attend compulsory education in 
Canada merits special attention. Hence, this MRP will propose a pilot project that initially focuses on youth who have graduated from Ontario high schools. Based on the consideration of schools as important social spaces with significant implications for youth negotiating legality and belonging (Young 2013), and research showing that children and youth in the school system internalize the idea that PSE is a sign of success and a guarantor of upward mobility (Gonzales, 2015).

For youth with PLS, the belief in the power of education results in a reality that is temporarily “eclipsed by a pervasive sense of promise and optimism" (Gonzales, 2015, p.57) through their participation in the school system. Their coming of age and high school graduation instead results in a process that mimics "waking up to a nightmare" (Gonzales, 2015, p.95). The realization that their lives have been further pushed to the margins of society and that their coming of age is itself a turning point (e.g. transition to illegality) (Gonzales, 2015). This transition into "illegality" (Gonzales, 2015) marks a rigorous negotiation of complex memberships in a community where youth are culturally and linguistically integrated, but legally excluded (Gonzales, 2015). The outcome of this process is a growing pool of educated people obliged to reshape plans and lower aspirations while friends and classmates with permanent status (i.e. recognized citizenship) advance through the various stages of life and professional careers.

This wasted talent and assembly of deferred dreams has devastating emotional and economic consequences for youth and on Canadian society as a whole, therefore, there is a paramount urgency for the creation of sustainable pathways to PSE for this population. It is important to 
note that my analysis applies to individuals with PLS in general, and is not subject to youth alone.

This paper will explore the possibility of expanding access to PSE for students with PLS at Ryerson University, with the hope that this idea is subsequently implemented across Ontario and potentially nationwide. This initiative would admit academically qualified students into Ryerson, and implement a tuition equity policy that would honour students' residency in the province, waiving international fees. For this purpose, I conducted a jurisdictional analysis, outlining the regulatory framework that governs foreign nationals' access to post-secondary institutions (PSI) and the role and responsibilities Ryerson University would undertake by executing the project.

Moreover, this paper will explore the potential barriers students applying to Ryerson could encounter under current application processes, and propose viable solutions to ensure prospective applicants are not deterred from applying to the school. I will present an evaluation of financial barriers and a detailed analysis of provincial funding transfers, as well as funding initiatives at the national and international level that could be used to offset the substantial cost to admitted students. I will highlight Ryerson's suitability for a project such as this one, given the university's commitment to equity, diversity and inclusion (EDI) and its intention to be a City Builder, and lastly, I will address future steps and substantive recommendations for the successful implementation of a project like this.

There are several arguments to support this project, and the value of each greatly depends upon one's philosophical and political stance. One can appeal to the moral and ethical obligation we have as a society to ensure youth reach their full potential and pursue their dreams. One can also highlight the detrimental effects of precarity and isolation on youth, and society as a whole. 
Nevertheless, what remains an unequivocal fact is that the initial investment in youth's compulsory education will pay relatively few economic dividends if this youth then continue to be denied PSE, and consequently are unable to obtain higher-paying jobs. Moreover, there is a looming economic and policy crisis that is fast approaching in the form of the mass retirement of the "baby boomer" generation. Expanding access to PSE to students with PLS could help mitigate the ripple effect this mass retirement will cause on the economy, while at the same time, providing this marginalized group with educational tools that will significantly benefit society, as well as presenting a pathway for regularization if existing immigration programs are reformed.

\section{$\underline{\text { Precarious Legal Status Defined }}$}

My original focus was solely on those who I believe live in the greatest state of precarity. People whose fear and jeopardy of detention and deportation is omnipotent, and whose precarity of status is based on being completely out of one; individuals who are often referred to as "undocumented" or "illegalized" (Bauder, 2012; P. Villegas 2013). The reality is that immigration policies and practices are always too specific, rigid (and oftentimes contradictory) to integrate immigrants with complicated immigration trajectories or even those with simpler ones. The complicated web of processes and the various less-than-permanent resident statuses have a devastating impact on the emotional, psychological, and physical state of a person, their primary social units and networks (Bernhard, Goldring, Young, Berinstein, and Wilson, 2007). These policies and practices ignore the range of status/non-status immigrants are forced into by the state, and instead blame the lack of access to services and regularization on the individual. It is crucial to understand that access to PSE, financial assistance, and domestic tuition fees, 
(amongst other things), is not only limited to those who completely lack immigration status, rather anyone with a precarious one.

I use the term precarious legal status (PLS) because it accounts for "multiple forms of irregular or 'less than full' legal statuses, without falling into a dichotomous approach to theorizing illegality" (Goldring, Berinstein and Bernhard, 2009; 2). It allows for the inclusion of statedefined legal categories -including, but not limited to:

- refugee claimants

- refused refugee claimants (with or without rights to appeal)

- humanitarian and compassionate ground applicants (prior to their initial approval)

- pre-removal risk assessment applicants

- undocumented and failed applicants from a moratorium country

- undocumented/illegalized people (whether they have overstayed a visa or a removal order)

and refers to authorized and unauthorized forms of non-citizenship that are deeply rooted in conditionality of presence and access (Goldring, Berinstein and Bernhard, 2009, Goldring and Landolt, 2013).

The aim of using PLS, instead of referring to a specific category, is to include those who are often overlooked: youth whose position in Canadian society is characterized by ambiguity and precarity, and whose everyday experiences are defined by their liminal legality. The concept of liminal legality was coined by sociologist Cecilia Menjívar (2006) to highlight the in-between areas of immigrant lives in the United States. Legal limbos that, more often than not, persist indefinitely and result in endowing immigrants with mixed memberships that underscore their complex legal statuses (Menjívar, 2006). Menjívar's work also emphasizes that conditions of inclusion and exclusion are actively created through everyday practices, and not just through official immigration policies. 
The conditionality of presence, uncertainty of access, and the arbitrary bureaucracy, immigration policy has over people with PLS - in other words the liminal legality Menjívar is referring to can be observed in a recent article by The Canadian Press (2017). The article noted a government analysis that projected refugee claimants could eventually wait a staggering eleven-year for a hearing in Canada (Lynch, 2017). This estimate only accounts for the average time of a successful applicant, and does not indicate a projection for a refugee claimant whose application is refused. The article highlights the lengthy and non-linear trajectories people with PLS often face, and is a vivid reminder of the proliferation of precariousness and the mediocracy of immigration policy in Canada. 


\section{POSITIONALITY STATEMENT}

My passion in this initiative stems from my own personal struggles to obtain access to PSE both in the United States and in Canada.

I confess that throughout the conception of this MRP I often hesitated about publicly sharing my experiences. I was conflicted not because I was ashamed of my journey, rather because this process entailed peeling back many layers of trauma and of all-consuming feelings of inequality and injustice I struggled daily to forget. Sharing my experiences also involved breaking the informal code of silence that my family and I instilled around this dark chapter in our lives. Nonetheless, I do strongly believe exploring these feelings provided me with much-needed healing and this paper with a profound awareness of the various complexities that are often overlooked by someone who has not experienced a similar journey.

My journey as an immigrant, like the journey of millions of people, has been filled with broken dreams, heartache, frustration, resilience, agency and love. In September 2000, my mother, a single parent of three children, made the frightening decision to leave Colombia for the United States of America. The details for our departure are part of a painful period in our lives and are the subsequent reasons for our status in Canada.

We arrived in Miami, Florida and resided there without immigration status for seven years. Although I was always aware of our lack of status, I cannot say I fully understood the extent and severe implications this had in our lives. The all-consuming fear of detention and deportation, adding to the stigmatizing mark of our "illegality" made my mother instill a code of silence around the topic in an effort to not be "found out." I never spoke about this significant aspect of my life outside a very select group of people, who comprised mostly of family and friends who 
helped us settle along the way. Therefore, my interactions with teachers, strangers and peers were always calculated and cautious.

The reality of being undocumented became increasingly palpable as I grew older. Getting a parttime job, a valid form of identification, thinking about traveling or post-secondary education were unattainable because they require legal immigration status. Nonetheless, the various introductions of the Development, Relief, and Education for Alien Minors Act, commonly known as the DREAM Act provided me with immense hope. The DREAM Act was a bipartisan federal legislation aimed to create a pathway to citizenship for undocumented children who grew up in the States. The political traction around the DREAM Act during this time made me hopeful for the future and allowed me to envision a day where I had not only earned a post-secondary degree, but also legalization.

I closely followed the debates and legal commentary around the Act through high school, and slowly transformed myself into a "model" student in anticipation of the legislation. I struggled academically during my freshman and sophomore years, which made getting to the top of my class that much more difficult. I attempted to supplement this "weakness" in my imaginary college application with extra-curricular activities. By senior year, I had been a part of the swimming team, and a member of various student clubs, an officer of my graduating class, manager of the boys' soccer team, president of the Spanish Club, and editor-in chief of school's yearbook. Every one of these efforts was made in an attempt to validate my belonging and membership in American society; and as a way to normalize my increasing social and political exclusion. 
By high school graduation, the DREAM Act had failed to pass and my world was rapidly shrinking. There was talk about states exploring the option of introducing in-state legislation aimed at providing numerous benefits for undocumented status, such as access to in-state tuition, financial aid or eligibility for certain scholarships, but the news of ramped-up deportations sowed fear among the community. It was then that my mother and I made the terrifying decision to leave the United States with my younger brother and reunite with my older sibling, who a few years prior had made it to Canada.

We arrived in this country on July 2007 and waited two years for our status to be decided. In retrospect, this was a brief time considering the current backlog at the Immigration and Refugee Board of Canada (IRB). Every passing day presented another blocked opportunity to get an education and be fully settled. In April 2010, I was accepted into the Law and Society program at York University, and finally began my academic career and have not stopped since.

Although I originally had a different project in mind for my MRP, a conversation with my advisor, Dr. Harald Bauder, steered me in the right direction and resulted in the conception of this initiative. The purpose of sharing this information with the reader is to situate myself, and my biases within this project. It is to underscore the internal turmoil I felt growing up due to the lack of access to PSE and to put a face on an issue we disregard often on the account of forced anonymity. 


\section{METHODOLOGY}

The overall goal of this project is policy development around the expansion of access to PSE for students with PLS in Canada, and the primary source of data for this initiative is public records. Given that this project is of an explorative nature, as scant research exists on the topic particularly in the Canadian context, I felt document analysis was the best-suited qualitative research method for this undertaking. This decision was made after carefully considering that policy analysis relies on specific research strategies designed for information gathering and evaluation (Bowen, 2009). Document analysis has been noted as a systematic procedure for the review of a large volume and variety of documents. Like other analytical methods in qualitative research, document analysis requires that data be examined and interpreted to elicit greater understanding and meaning around a topic (Bowen, 2009).

As noted, the hope of this initiative is to be expanded at the provincial and national level. Nonetheless, given the brief (three months) period in which this project was undertaken I decided that the best research strategy to achieve a high standard of reliability would be an instrumental case-study of Ryerson University. Reliability within research refers to dependability and consistency (Eisner, 1991). To obtain reliability, the researcher must employ an appropriate scale and appropriate sample size to produce stable and consistent results (Neuman, 2016).

According to Sake (2013), an instrumental case-study is mainly done to provide insight into an issue or to produce a generalization. Instrumental case-studies then, play a supportive role and serve to facilitate understanding around a topic (Sake, 2013). Thus, a case-study of Ryerson University was reasonable in size and scale, but also allowed for an in-depth examination of the topic while encouraging the consideration of multiple angles. This research strategy flushed out 
intricate details that resulted in richer and more comprehensive recommendations. It also resulted in a sort of "road-map" that could be utilized by other universities in Ontario interested in undertaking similar initiatives.

In this project, reliability was also achieved by thoroughly reviewing multiple sources and anticipating areas to be explored further. This strategy was used to guard myself against the allegation that the recommendations made here are simply an artifact of a narrow research and/or personal bias. Relevant legislation, regulations and case law on the subject matter were examined and became part of the jurisdictional component of this project. My legal-analysis is primarily based on a 2009 report made by then Osgoode Hall Law student, Meghan Wilson, titled Access to Postsecondary Education for Undocumented Immigrants. The purpose of the report was to aid advocates on their "Right to Education Campaign" and was conducted in response to a request for legal analysis to the Parkdale Community Legal Services by No One Is Illegal, and thenactive Education Taskforce.

Wilson's report was made available to me by a current member of No One Is Illegal and thenmember of the Education Taskforce. Efforts were made to contact the author of the report via email, as she is a practicing immigration lawyer in Toronto. She graciously agreed to informally meet with me to discuss her findings, and provide insight into future steps under current immigration programs for regularization. Due to time constraints on both ends, this meeting did not take place before the finalization of my MRP. I also used the legal analysis skills and immigration knowledge I obtained during my undergraduate and graduate education in the Law \& Society program at York University, and Immigration and Settlement Studies program at Ryerson University (respectively), and the experience gained throughout my professional 
experience. These skills aided me during the revision of Wilson's work and the conceptualization of my MRP.

For the other components of this initiative, I evaluated various sources and held informal meetings with a knowledgeable source. The Ontario Universities Application Centre (OUAC) and Ryerson's University websites were reviewed to assess possible barriers and current information available for prospective applicants. Reports by the Canadian government and NGO's, on the benefits and current barriers of access to PSE for marginalized populations were reviewed. Most reports did not focus on or mention PLS individuals, but rather, targeted other marginalized groups. Academic pieces on the topic from prominent Canadian authors were also reviewed (e.g. Aberman 2017; Goldring and Landolt, 2013; F. Villegas 2013; Young, 2013). Although they provided incredible insight, and provided the basis of this project, it became clear that the search field needed to be expanded to include international research.

The expansion of the search yielded important sources of advocacy campaigns drawing on approaches in the United States, and a variety of initiatives and empirical research at the international level. From there, sources were selected based on the quality of the source and their potential for comparative analysis, and it was through this research strategy that I came across the work of American sociologist Roberto G. Gonzales. Gonzales has conducted extensive and invaluable research on this topic and his work greatly influenced the conceptualization of this project. Specifically, his book Lives in Limbo, Undocumented and Coming of Age in America (2015), which is based on an in-depth study that followed one hundred and fifty undocumented young adults in Los Angeles for twelve years. Gonzales' long-term study provided critical 
insight into the devastating effects of denying access to post-secondary education or expanding access without a strategy for regularization.

\section{Sampling Frame}

While any initial project expanding access to PLS would inevitably exclude some individuals, it is important to start somewhere and develop from there. The target group for this MRP stems from the work of the Uprooted U Program, and my informal meetings with $\mathrm{PhD}$ candidate and Research and Project Coordinator at the FCJ Refugee Centre, Tanya Aberman. Uprooted U is an innovative educational initiative designed to address the gaps in access to PSE for precarious status youth. The program currently runs a grassroots approach that introduces students to university-level academic standards, critical thinking, reading and writing skills, while at the same time educating the community on the unique barriers newcomer youth between the ages of 14 to 24 face in Canada.

This MRP will focus on advocating for current students and recent graduates of high schools in Ontario with PLS. The decision was made in part given my own personal experience accessing PSE, the work of the Uprooted program, and after considering the unique experiences of (temporary) integration faced by youth with PLS. This (temporary) integration is rooted in their membership in what the academic literature often refers to as the 1.5 generation (Rumbaut 2004), which stems from the fact that they fit somewhere between the first and second generation. This classification means they are neither the first generation, since they did not choose to migrate, nor do they belong to the second generation because they were born and spent part of their childhood abroad (Rumbaut 2004). Moreover, the 1.5 generation arrives in the country of residency as minors and their education is largely completed in that country (Rumbaut 2004). 
The completion of education in Canada, particularly Ontario, is of crucial importance for this MRP. Given that although the 1.5 generation has a strong association with their country of birth, its primary identification is affected by experiences of growing up as Canadians. Therefore, it could be argued that youth with PLS have a more distinct experience of liminality than youngadults, and adults who have not attended school in Canada, since their participation in the school system presents them with unique experiences of social and cultural (temporary) integration (Gonzales, 2015). Consequently, although I acknowledge that youth with PLS are not the only ones affected by the lack of sustainable pathways to PSE and that access must be expanded to all individuals with PSL, I find that their experience of (temporary) integration merits special attention. 


\section{PART I \\ SETTING THE STAGE}

\section{CH. 1 - THE LEGAL CONTRADICTIONS OF THE RIGHT TO EDUCATION}

Since the adoption of the Universal Declaration of Human Rights, the right to education has been reaffirmed in several treaties and legal instruments at the international, national and provincial level. Article 13.1 of the International Covenant on Economic, Social and Cultural Rights, for example clearly states the right to everyone to education, as an indispensable means of realizing the full development of human potential, sense of dignity and effective participation in a free society (UN General Assembly, 1966). Hence, education is increasingly recognized as one of the best financial investments states can make (UN General Assembly, 1966).

Nonetheless, the conceptualization of this right in Canada, has mostly centered around children, and the policies and practices relating to access are often too specific, rigid (and oftentimes contradictory) to fully integrate youth with PLS. In light of this, I decided to include a very brief synopsis of the victories as it provides around the conceptualization of the right to compulsory education for minors in the province Ontario, and the City of Toronto, as it provides insight into possible challenges and future steps for the expansion of access to PSE.

Although education falls within the jurisdiction of the provinces, until 1993 the only affirmation of the right to education for immigrant children with PLS was found at the federal level by way of s.30(2) of Immigration and Refugee Protection Act (IRPA) (Wilson, 2009). This section of IRPA states that "[e]very minor child in Canada, other than a child of a temporary resident not authorized to work or study [a visitor], is authorized to study at the pre-school, primary or 
secondary level" (SC 2001, c.27). Hence, in theory, the right to education is guaranteed as long as the child's parent(s) are not visitors in Canada, and until the child reaches the age of majority.

The lack of affirmation of the right to education for children and youth with PLS in Ontario resulted in substantive advocacy efforts in the 1990s and 2000s that lead to the incorporation of s.49(1) into the Education Act. (F. Villegas 2013). This section essentially reaffirms at the provincial level, the right to compulsory education for youth under eighteen years of age regardless of immigration status (Education Act, R.S.O.1993, c.11, s.21). This reiteration was a significant victory for students, parents and advocates alike given that the Education Act is the main piece of legislation governing public education in the province (Wilson, 2009).

Nevertheless, despite having policies at the federal and provincial level clearly reaffirming the right to education, parents and guardians with PLS often encounter obstacles registering their children (F. Villegas 2013).

The problem around registration continues to be a contentious issue with school boards and remains a focus of advocacy campaigns. The lack of appropriate training of front-line staff, who are the undeniable gatekeepers of services, often results in parents encountering problems when enrolling new students. Particularly since the inclusion of section 49(1) of the Education Act refers to entitlement of admission without a fee, which is only guaranteed to Canadian citizens and permanent residents under the law (F. Villegas 2013). Meaning, individuals with study permits or visitor visas are still liable for tuition fees because they are considered to be international students. Therefore, the fear of losing international student fees by school boards is a key factor in restricting access to education. The implications for access to compulsory education for individuals who are classified as international students are comparable to the fears 
and possible obstacles around the expansion of access to PSE, and is an issue that will be addressed in detail in the "reoccurring concern" section of this paper.

Advocacy campaigns around registration lead to the passage of a "Students Without Legal Immigration Status Policy”, also known as “Don't Ask Don't Tell” (DADT), by the Toronto District School Board (TDSB) in 2007 (TDSB minutes May 16, 2007). DADT represents another effort to uphold the right to education of minors, and ensure school officials within the TDSB do not ask for or share the immigration status of students, their parents or guardians (TDSB minutes May 16, 2007). This policy established schools as sanctuary zones in order to ensure safe access to schooling (F. Villegas 2013). Yet, this was not a national or even provincial policy, but rather a TDSB initiative. In addition, its implementation has been slow and somewhat ambiguous resulting in the continued exclusion of students from school.

Nonetheless, these policy changes appear to highlight that there is overarching sentiment that immigration status and the right to education should not be convoluted. This sentiment was captured in June of 2008, when then Premier Dalton McGuinty stated that:

If a child shows up at the door looking for an education, our responsibility is to provide that education. If the federal government feels that child, that family, should not be in our province, then that is something they should do something about. But we are not going to start picking and choosing which kids are going to be allowed into the classroom.

(Babbage, 2008)

MacGuinty's statement causes one to wonder then, why, when it comes to PSE, it becomes acceptable to "pick and choose" which students should be permitted access based on their immigration status? Why, after high school graduation, do youth with PLS, who are as academically qualified as their peers, have to stand idle due to their status, and are unable to 
access PSE and the future benefits this can provide? This is one of the central questions driving this MRP. 


\section{CH. 2 - JURISDICTIONALLY}

In order to assess the expansion of access to PSE by Ryerson University, a jurisdictional analysis of the regulatory frameworks that govern foreign nationals access to PSE in Canada needed to be conducted. This section draws heavily on a 2009 report made by then Osgoode Law student Meghan Wilson titled Access to Postsecondary Education for Undocumented Immigrants. The premise of that report was to explore the legal position of undocumented students wishing to pursue PSE. Given that this initiative is not only advocating for the expansion of access to undocumented students but rather a wider group, and the focus is on the legal liability of Ryerson University if such steps are taken, Wilson's legal analysis was supplemented with additional information and research.

\section{REGULATORY FRAMEWORK}

\section{1 - Immigration Act}

The Constitution Act of 1867 imposes a framework of the distribution of legislative powers amongst the federal and provincial governments (Russel, Knopff, Bateman and Hiebert, 2008). S.95 of the Act grants concurrent power to legislate in relation to agriculture and immigration to the federal and provincial legislature (The Constitutional Act, 1867). This legislative power is granted with the qualification that provincial law "is not repugnant to any Act of the Parliament of Canada" (The Constitutional Act, 1867). In other words, the provincial government has the ability to legislate in matters relating to agriculture and immigration within its territory, but under the doctrine of federal paramountcy, federal legislation will always be considered supreme, and prevails. S.91(25) of the Act, also grants legislative authority over the "Naturalization of Aliens" to the federal government (The Constitutional Act, 1867). Consequently, a matter has been defined as relating to the "naturalization and aliens" is 
considered exclusively within federal jurisdiction, which systematically invalidates provincial legislation on the same issue (Wilson, 2009).

The Immigration Refugee and Protection Act (IRPA) is the framework legislation that sets out in general terms the rules governing the admission, terms of residence, removal and status of foreign nationals in Canada (IRPA, SC 2001, c.27). The Act also establishes what constitutes lawful documentation for non-citizens and the activities they are permitted to pursue based on their status (Wilson, 2009). Most of the content of immigration law is regulated by the Immigration and Refugee Protection Regulations (IRPR), which are passed by Cabinet (Carasco, 2007). Supplementing these, are policy and program manuals drafted by the department of Immigration, Refugee and Citizenship Canada (IRCC).

Although together s.95 and 91(5) of the Constitution Act of 1867 grant the legislative authority in the area of immigration chiefly within federal jurisdiction, there is a joint recognition of the need to cooperate in immigration matters between the federal and provincial legislature under IRPA. S.8 and s.9 of IRPA allows for federal - provincial agreements on immigration (IRPA, SC 2001, c.27). The agreements outline in specific terms the responsibilities of the respective parties, and have also allowed for the provinces to nominate individuals for selection as permanent residents in order to further their own economic and cultural goals (IRPA, SC 2001, c.27). The value of these agreements in future regularization initiatives will be explored in later sections of this MRP.

With regards to PSE, s.30(1) of IRPA and s.s 212 of IRPR both state that a foreign national may not study in Canada unless authorized to do so by a study permit or by the Regulations (IRPA, SC 2001, c.27; IRPR S.O.R./2002-227). For the Act and corresponding Regulations, studies are 
considered to be any studying undertaken at a university or college, or any course of academic, professional or vocational training (IRPA, SC 2001, c.27; IRPR S.O.R./2002-227). According to s.215 of IRPR, given that most authorized stays in the country are for a period of six months or less, a foreign national can legally study in Canada without a permit if the course or program of study is completed during this time (IRPR S.O.R./2002-227). While this legal loophole creates a limited but real opportunity for some individuals, given that very few post-secondary programs are six-months or less in duration and that the students being targeted under this initiative have been in the country for many years before applying for PSE, this is not a viable legal recourse.

Therefore, under current legislation, an individual wanting to pursue PSE in Canada must apply for a study permit. S.216(1) of the IRPR, indicates that under most circumstances applications must be processed from outside of the country (IRPR S.O.R./2002-227). Nonetheless, there are a few exceptions for applications within Canada, which are all listed in ss.215(1) and 207 of the IRPA (IRPA, SC 2001, c.27). Some of these exceptional cases would avail youth with PLS, in particular those who are awaiting a decision of an application or judgement from a Court of law. However, F. Villegas (2013) argues that the process an applicant must undergo in pursuit of a study permit is a "highly classist, racist, and ableist" undertaking (p. 262). This is due to the financial and medical requirements the applicant must provide to the federal government before successfully obtaining a study permit. Moreover, the financial barriers of meeting the application requirements for a study permit, and their subsequent qualification (if successful) by PSI as international students, does not remove the economic barrier of obtaining access to PSE.

What is of vital importance here, is that there are no sanctions or provisions under IRPA or IRPR to punish institutions that do not enforce the requirement of a student permit and admit people 
with PLS. Therefore, even though granting potential students could be in violation of s.30 of $I R P A$, Ryerson University would not face any sanctions for expanding access to PLS because no sanctions are stipulated in the Regulations. This process only requires negative obligations for Ryerson, and is possible given the autonomy granted to PSI in Ontario by the Education Act.

\section{$\underline{2.2-\text { Education Law }}$}

The jurisdictional analysis of education law has been divided into two sections. The first component sets the stage, and provides legal arguments for this project at the provincial level. The second component highlights how Ryerson University and other PSI in the province can utilize their extraordinary level of autonomy to expand access to PSE for people with PLS.

\subsection{1 - Provincial Level}

In Canada, there is no integrated national system or federal department of education. Rather s.93 of the Constitution Act, 1867 states that education falls within the exclusive jurisdiction of the provinces (The Constitutional Act, 1867). The only limitation on provincial authority is beyond the scope of this initiative, and relates to Roman Catholic and Protestant denominational education (i.e. par. 1-4 of s.93). Therefore, one could argue that by virtue of the provinces' sole legislative power over matters of education, Ontario's decision regarding the possible admission and funding of youth with PLS into PSE is within their jurisdiction and could take precedence over the IRPA (Wilson, 2009). Nonetheless, if the federal government argues that this matter relates to the regularization of "foreign nationals," which is exclusively within federal jurisdiction, it would invalidate provincial legislation on the same issue (Wilson, 2009).

In light of the fact that constitutional challenges relating to the divisions of power are often 
referred to Courts for adjudication, the legal system has developed intricate processes and evolved legal doctrines to decide whether the challenge is intra vires (within the powers) or ultra vires (beyond the powers) (Hogg, 2007). Based on Wilson's (2009) report, I highlight three legal doctrines that might prove useful when Ontario or any other province decides to take up this matter: pith and substance, necessarily incidental, and double aspect. The pith and substance doctrine relates to the true intent of said legislation, and guides its subsequent classification for purposes of division of power questions (Hogg, 2007). In this instance, Ontario would need to prove that the true intent of the legislation is to educate and not regulate "foreign nationals," given that regulation falls within the jurisdiction of the federal government and would render this policy invalid.

The effect on the regulation of "foreign nationals" by the expansion of access to PSE could then be explained by the province via the necessarily incidental doctrine; which establishes that a law may have an impact on matters outside of the enacting legislature's jurisdiction, as long as the impact is "necessarily incidental" to attaining the primary object of the law (Hogg, 2007). ${ }^{1}$ In this case, Ontario would have to prove that the impact on the regulations of "foreign nationals," is incidental and necessary if access to PSE is to be expanded to people with PLS. A compelling case in favor of the right to education must be presented, and one that is centred around the jurisdictionally of the province in this matter. Therefore, reiterating that the true intent of the law is education and not the regulation.

Lastly, the third legal principle that could aid Ontario's arguments in favor of expanding access to PSE for people with PLS is the double aspect doctrine. This legal dogma states that legislation

${ }^{1}$ For legal test see General Motors of Canada Ltd. v. City of National Leasing (1989) SCC. 
can in one aspect and for one purpose fall within federal jurisdiction, but may in another aspect and for another purpose fall within provincial jurisdiction (Hogg, 2007). ${ }^{2}$ The double aspect doctrine captures the essence of the predicament at hand, and can aid provinces that may want to undertake a project like this one in the near future. Nonetheless, the legal question relating to the jurisdiction of a project like this has not been tested in Court. Besides, and given that there tends to be judicial restraint when adjudicating division of powers questions, and we are governed by a doctrine of federal paramountcy, it is improbable that a Constitutional challenge such as this one would be successful. ${ }^{3}$ Therefore, committed advocacy at the local, provincial and federal level are needed to ensure access to PSE is expanded in all PSI in Canada.

\subsection{2 - Local Level (PSI)}

Compulsory education in Canada is strictly governed by a provincial Education Act.

PSIs, on the other hand, are largely autonomous and are governed by the Ontario's Post-

Secondary Education Choice and Excellence Act 2000 (PSECE). Pursuant to the PSECE Act, all institutions require an act of the Legislative Assembly of Ontario or the consent of the Minister of Training, Colleges and Universities to offer any program leading to a degree (Wilson, 2009; PSECE Act, 2000, S.O. 2000, c. 36, Sch.). Once approved, each institution in the province is granted its own individual act of incorporation. The Act of incorporation gives the board of directors of said institution full responsibility over academic and administrative matters (Wilson,

\footnotetext{
${ }^{2}$ For legal test see Hodge v. The Queen (1883) and Multiple Access Ltd. v. McCutcheon (1982) SCC.

${ }^{3}$ Nonetheless, the increasing defiance of local governments to federal legislation relating to immigration enforcement and access to public services in the United States could provide important legal strategies to provincial governments here in Canada. See State of Washington, et al., plaintiffs-appellees, v. Donald Trump, President of the United States, et al., defendant-appellants No. 17-35105 and Texas, et al. v. United States, et al., No. 1:14-cv-00254 (S.D. Tex.), for more information.
} 
2009; PSECE Act, 2000, S.O. 2000, c. 36, Sch.).

Ryerson University is established and operates under the Ryerson University Act, 1977 (Ryerson University Act, 1977 S.O., 1997 c.47). It has the power to set its own admission standards and degree requirements (PSECE Act, 2000, S.O. 2000, c. 36, Sch.); and after the deregulation of 1998, it also has the authority to set its own tuition fees (Boggs, 2009). Therefore, though it could be argued that the absence of a national strategy has consequences relating to inconsistent funding schemes and a lack of nation-wide mechanisms to support post-secondary development, it could also be said, that given their outstanding level of autonomy, Ryerson and other universities and colleges in the province are better positioned to respond to local and regional issues, such as the initial expansion of access to PSE for people with PLS.

The feasibility of this expansion is supported by the lack of provisions under IRPA that require PSE to exercise due diligence in ensuring students comply with the Act, and the fact that it is not an offense for an institution to enroll a student without a student permit (Wilson, 2009; IRPA, SC 2001, c.27; IRPR S.O.R./2002-227). In essence then, it is a relatively simple policy for an institution to put in place because it only requires negative obligations. Moreover, mechanisms are already in place that allow people with PLS to apply to PSI in Ontario, all while strictly protecting the sharing of their immigration status. Therefore, the logistical aspect of this initiative is also within reach and will be discussed in the section below. 


\section{PART II INITIAL BARRIERS}

This section explores the procedural and financial barriers that would need to be addressed by Ryerson University to establish the successful implementation of an initiative intended to expand access to PSE for people with PLS. Though, it is important to emphasize that several other barriers need to be explored and subsequently addressed to guarantee prospective students are not put in unnecessary danger due to the lack of sensitivity around the topic by university staff, and support is available to them relating to all issues that might arise. Therefore, a long-term commitment from the school is needed. One that would not only come in the form of adequate resources to guarantee the appropriate training of staff and necessary research takes place, but also advocacy campaigns spearheaded by Ryerson amongst other universities in the city and province to gain the support needed before approaching the provincial and federal government.

\section{CH. 3 - PROCEDURAL BARRIERS}

To initiate an application to any university in Ontario, a prospective student must submit an on-line form through the Ontario Universities' Application Centre (OUAC); in specific cases applicants are also able to apply directly to the university. Consequently, the admission process for prospective students with PLS could be done through two mechanisms, both of which will be explored below.

\section{$\underline{3.1 \text { - Option 1: Through OUAC }}$}

According to the OUAC, prospective students and recent high school graduates have the option of completing the (101) or (105) Ontario Secondary School Application (OSSA). The eligibility criteria for both applications is attached as Appendix 1. Given that the initial target 
group this MRP is advocating for are attending, or recently graduated from, an Ontario high school, these students would be applying under the OSSA (101). Wilson (2009) found that the OSSA contains several options for applicants to indicate their "Status in Canada" (at time of applying), and that one must be selected, before proceeding to the next sections in the application. Hence, the OUAC acts as the first gatekeeper for prospective students with PLS by requiring them to disclose and confine their immigration status to rigid categories.

Wilson (2009) argued that applicants were constricted between selecting "Other - no status" or "International Student." She also noted the fact that the "Other - no status" option was available, indicating that the OUAC had anticipated that there would be students applying for Ontario universities that were in-between or without immigration status in Canada (Wilson, 2009). Most notably, this acknowledgment also emphasized that the OUAC is willing to process the student's application regardless of the immigration status in Canada (Wilson, 2009). However, Wilson (2009) found that after the successful completion of an application, said application is sent to the registrar office of the student's institution of choice. The institution then applies its own admission criteria to determine whether the applicant is eligible for admission (Wilson, 2009).

In order to corroborate the options described by Wilson (2009) were still available for prospective students, I created a dummy OSSA. A screenshot of the application has been attached as Appendix 2. I originally selected the OSSA (101), but given that I did not have any of the access codes, (which are provided to the students by a high school guidance counselor,) I was unable to continue. I called the Application Inquiries line, and spoke to a customer service representative, who after I briefly explaining the purpose of my research, suggested I tried completing the (105D) application. I requested the OUAC representative to confirm that the 
options relating to "Status in Canada" on the Personal Information Section were the same for OSSA (101) and (105). Confirmation was provided.

A couple of things are worth nothing. First, the "Status in Canada" options described by Wilson (2009) have slightly changed. The "International Student" option was renamed to "Student Permit," and a new option for "Visitor" has been added (Appendix 2). The "Other - no status" option was replaced by "No Status" and the option for "Other" was removed (Appendix 2). Youth completely lacking immigration status would be required to disclose it, a process that can be nerve-racking, and quite dangerous in some instances. For those who do have some form of authorized status in Canada, the changes limit the recognition of such under these rigid categories. The new status specifications in the application seem to highlight the dichotomous approaches that theorize illegality, that this project is trying to break-away from, while also displaying that the logic of risk management has filtered its way into the OUAC's mechanisms of processing student applications; since new filters have been put in place to ensure students get "properly" screened in/out by universities.

The disclosure of a student's immigration status, or lack-there-of, is a very sensitive topic given the devastating consequences this information can have if shared with the wrong parties. Nonetheless, the OAUC's information sharing mechanisms are strictly guided by the Ontario's Freedom of Information and Protection of Privacy Act (the FIPPA), which severely limits the disclosure of applicants' personal information (Wilson, 2009). Officials from the OAUC confirmed to Wilson (2009) that they would not disclose an individual's immigration status to anyone other than the institution indicated on the application; and that the only applicable circumstance under which they will release a student's information to other parties would be if 
they are required to do so by law, by way of a search warrant or other legally valid order (Wilson, 2009). Officials from the OUAC asserted that their main objective for requesting immigration information was to generate aggregate statistics, connect international students with relevant services available to them, and streamline universities determination process relating to registrations fees (Wilson, 2009).

\section{2 - Option 2: Apply Directly to Ryerson University}

Ryerson University, like many other universities in the province, has a mechanism already in place to bypass OUAC and allow students to apply directly. The Ryerson Application is mostly used by current/returning students, or people applying for part-time programs (Applications and Related Forms, 2017). Therefore, the criteria for the Ryerson Application could be expanded to allow prospective students with PLS to directly apply to the school.

An in-house application process could be beneficial for both prospective students and Ryerson University for several reasons. First, it would minimize the (potential) risk and anxiety of applicants, in disclosing personal and immigration information to multiple sources. Second, it would provide Ryerson with more control over the determination and specific requirements for tuition equity policies granted to this group. Third, it could in turn alleviate concerns around international students, who realistically have the ability to pay international fees and obtain a student permit without risking deportation, "sneaking through" as youth with PLS in order to access domestic tuition fees. I will address this anxiety in more detail in the reoccurring concern section of this MRP. 
The expansion of the Ryerson Application could be conceptualized, for example, around the Ontario Education Number (OEN). The OEN is uniquely assigned to every student who has attended school in Ontario (Ontario Education Number (OEN), 2017). Setting up an in-house application around the OEN could assist in the sharing of educational information from secondary schools, while also aiding in restricting who would be (initially) applying under this initiative, given that only Ontario students would have such information. Moreover, the OEN could allow the Ministry of Education to continue to track students, in order to generate aggregate statistics related, but not limited to, labour market, education trends, and demographics.

Regardless of the application process Ryerson decides on, a comprehensive study must be undertaken to ensure that appropriate mechanisms by the Registrars and Admissions office are put in place. These mechanisms should not only ensure proper sensitivity and training around the topic but would also provide prospective students with reassurance around the collection, management and release of their personal information. This could be done by highlighting the fact that as of 2006 both Ryerson University and OAUC are governed and guided by the same information sharing mechanisms (i.e. FIPPA) (Ontario's FIPPA R.S.O. 1990, c. F. 31.)

FIPPA makes PSI fairly secure places, given the strict rules relating to the sharing and disclosure of students' personal information. Therefore, the probability of a student's immigration status being arbitrarily reported to the IRCC is limited, considering the requirement of a search warrant or other legally valid order. Nonetheless, my intent is not to minimize the risk of detention and deportation for youth with PLS, in case the system fails to follow procedure. Rather the aim here 
is to highlight the overarching barriers currently in place, and find ways in which they can be overcome if the necessary changes and safeguards are put in place. 


\section{CH. 4 - FINANCIAL BARRIERS}

Expanding access to PSE for youth with PLS is critical but insufficient unless a tuition equity policy is implemented. A policy that would not only honor youth's continuous residency in the province but would also help alleviate the substantial financial barriers they would face, in light of not being able to access the financial assistance offered under the Ontario Student Assistance Program (OSAP). Please see Appendix 3 for eligibility criteria. It is precisely through a tuition equity policy that Ryerson's commitment to enacting policies that directly address one of the most marginalized and invisible groups will be tested given the (initial) financial hit the university will endure. This chapter will provide background information on current provincial transfer payments for PSE, as well as a brief history of tuition fees in Ontario. Moreover, it will explore some cost-effective ideas and international initiatives that could offset the financial barriers these students will endure, after being accepted.

\section{$\underline{4.1 \text { - Provincial Transfer Payments for PSE }}$}

As stated above, PSI in Ontario are legally autonomous bodies and have the authority to establish their own admission criteria and tuition rates. Nonetheless, most of the direct funding for PSE in Canada derives from provincial/territorial sources (Boggs, 2009). The balance of public PSE income in Canada is obtained from "tuition fees ( 21 percent), sale of goods and services (14.6 percent), federal government ( 9.3 percent), investment income ( 2.7 percent), and other income including philanthropic contributions (7.4 percent)" (The International Comparative Higher Education and Finance Project, 2010, p.1-2). In Ontario, provincial funding is distributed to institutions by the Ministry of Training, Colleges and Universities (MTCU), through grants which are based on the number of "eligible" students enrolled at a corresponding 
institution (Wilson, 2009). The eligibility category is set by the MTCU in the Ontario Operating Funds Distribution Manual (OPFDM) and is mostly contingent on a student's or their guardians' immigration status (OPFDM, 2010; Wilson, 2009). Please see Appendix 4 for more details.

It is the responsibility of PSI to see that no eligible student to be considered for a provincial education grant is unclaimed, and to charge ineligible students the equivalent of what is deemed as unsubsidized fees (aka international fees) (OPFDM, 2010; Wilson, 2009). The subsidy can account for two-thirds of the full cost of educating a university student (OPFDM, 2010). However, under the current criteria set by the OPFDM, PSIs accepting PLS students would lose the tuition subsidy granted by the Ministry. This would represent a noticeable loss for Ryerson, albeit not an unmanageable one. Nonetheless, as stated in s. 4.2 Ineligible Student of the OPFDM, since 1994 there seems to be a policy that allows universities to consult the Ministry before including a student for operating grant purposes (OPFDM, 2010). This shows that a case could be made to the Ministry in the future that might result in prospective students with PLS being included.

\section{$\underline{4.2-\text { Tuition Fees }}$}

Prior to the late 1970s, international and domestic students were not charged different tuition fees and their education was equally subsidized by the government (Boggs, 2009). How the 1976 negotiation of federal transfer payments to the provinces, the federal government suggested the introduction of differential tuition fees as an acceptable way for intuitions to generate additional revenue and ease the burden on provincial transfers (Boggs, 2009). Since

then, provincial governments have cut and eliminated most grants that had previously been provided to PSI for funding of international students (Boggs, 2009). 
Tuition fees in Canada have skyrocketed for both international and domestic students in recent years, as federal and provincial governments further cut funding for PSE (Boggs, 2009). In Ontario, there has been a substantial decrease in provincial post-secondary transfers over the past two decades, and it has been argued that provincial grants to Ontario universities, on a perstudent basis, are the lowest in the country (CFS, 2013). Thus, Ontario universities educate more students for less provincial funding than universities in other provinces. Decreased funding from the provincial and federal government resulted in the push for the deregulation of fees for international students by some provincial governments, such as Ontario (Boggs, 2009). Other provinces, such as Newfoundland and Labrador, have taken an aggressive stance on lowering tuition fees for all students, including in- and out-of-province and international students (Macdonald and Shaker, 2014).

The deregulation of international fees has been used by PSI as an informal replacement for loss of government funding (Kirby, 2007). The continued decrease in government funding to PSE in Canada has also resulted in institutions pursuing "creative" ways to download more costs onto students, by way of compulsory fees students must pay on top of their tuition fees (Macdonald and Shaker, 2014). Compulsory fees continue to be on the rise, and depending on the province are more often than not unregulated (Macdonald and Shaker, 2014). The increase in tuition and auxiliary fees adds to the lack of access to funding students, making the financial barrier for youth with PLS that much greater to overcome.

This brief overview of tuition fees in Canada underscores a couple of things. First, not too long ago, students in Canadian universities that were categorized as "international," were equally funded by both levels of government. Second, some provinces, such as Newfoundland and 
Labrador, have continued to offer funding to this group. Therefore, although this paper is advocating for a tuition equity policy for a very particular group, these facts show that if adequate advocacy campaigns are put in place, and the eligibility criteria for provincial transfer payments is expanded, Ryerson could suffer relatively small and manageable economic loss. Third, while implementing this initiative would represent an economic loss for the institution, this loss is declining relative to the total cost of educating a PSI student due to the continuing decline of the provincial share of funding PSE.

\section{$\underline{4.3 \text { - Student Aid }}$}

As noted previously, youth with PLS are ineligible for provincial or federal financial aid under the current guidelines. Nonetheless, history shows that effective advocacy campaigns can result in victories regarding the expansion of the eligibility criteria for OSAP. Prior to 2003 convention refugees and protected persons who had not received their permanent residency before enrolling in PSE, were not eligible for federal student loans and most provincial student loan programs (Slobodian and Kits, 2003). As of August 1, 2004, protected persons are eligible for funding from both the federal and provincial portions of the Canada-Ontario Integrated Student Loan Program (Slobodian and Kits, 2003). A successful advocacy campaign involved a broad spectrum of community members and highlighted a key point: students would have to qualify under financial criteria and repay their loans like any other applicant (Slobodian and Kits, 2003), therefore debunking the misconception that they should be regulated under different eligibility criteria.

The success of expanding access to student aid to refugees and protected persons in Canada, could serve to inform future advocacy campaigns aimed at youth with PLS, considering that a 
similar argument would be made for them. Although it could be argued that their risk of deportability might affect the likelihood of loan repayment, it is important to highlight that permanent immigration status is not a guarantee for loan repayment. Rather, we must consider that student financial aid needs to be available on a need-basis, in order to ensure that successful applicants are able to afford the increasing cost of PSE.

\section{$\underline{4.4 \text { - University and Community Partnerships }}$}

One of the ways in which financial assistance could be provided to students with PLS is though the creation of special need-based and academic merit scholarships, made on the basis of residency and private funds. University and community partnerships in England could present a model in this respect.

England - The Queen Mary University of London \& The Article 26 Project

In 2007, the Education (Fees and Awards) (England) Regulations Act (EDAER), changed the definition of "home" (UK/EU) and "overseas" students for the purpose establishing tuition fees (EFAER, 2007, No.779). Besides transferring the onus on to individual students to satisfy the institution that they meet the criteria to be classified as "home" status (EFAER, 2007, No.779), the legislative change revoked domestic tuition fees for refugee claimants (EFAER, 2007, No.779). Since then, each university has been able to decide whether they want to reduce or waive "overseas" fees for refugee claimants, but if they choose to do so they would not be entitled to transfer payments from the Department of Education (EFAER, 2007, No.779).

In response, a number of universities and community initiatives in the UK have countered the government's decision by creating special scholarships that allow a small number of refugee 
claimants, and students with discretionary leave to remain (DLR), to study at domestic rates and provide bursaries to cover maintenance fees (Refugees Into Teaching, 2013). At the university level, the Queen Mary University of London was among the first universities to enact this funding model, and the number of universities following suit keeps on growing. Prospective students apply through the regular application process to the university and must also apply for the "Asylum Seekers Bursary" (which is said to be accepted automatically as long as the student meets the eligibility requirements) (Asylum Seekers Fee Concession, 2017. Please see Appendix 5 for more details). In recent years, Queen Mary has increased the provision of the bursaries to refugee claimants as a response to the refugee crisis in Europe; and is said be continually reviewing provisions of funding and services to better assist this group (\#RefugeesWelcome: QMUL Activity In Support of Refugees, 2017).

At the community level, an initiative created by the Helena Kennedy Foundation, runs an award called Article 26 (Refugees Into Teaching, 2013). The project provides access to PSE by working in partnership with universities in England committed to supporting refuge claimants who were negatively affected by the legislative changes that revoked domestic tuition fees for them (Article 26, 2017). The Article 26 award funds a small number of "home" tuition-fee bursaries for successful applicants (Article 26, 2017). In order to qualify, students need to submit a separate application to the Helena Kennedy Foundation, stating their case, after which a decision is made by a committee (Article 26, 2017).

The special scholarships created by Queen Mary University and the funding provided to students through the Helena Kennedy Foundation are examples of successful partnerships between the community and universities. Both of these initiatives could be undertaken at Ryerson University 
to alleviate the financial barriers for youth with PLS after admission into the university.

Moreover, in light of the uniqueness of a project like this one in Canada, Ryerson could utilize its prominent place in our community to leverage community partners to financially contribute to this initiative. If the community is successful in future advocacy campaigns to expand access to student aid for this group, a private-sponsorship model could be used by Ryerson to offset the financial cost of expanding access to PSE for youth with PLS. 


\section{PART III \\ ARGUMENTS FOR AND AGAINST THE EXPANSION OF ACCESS TO PSE}

\section{CH. 5 - REOCCURRING CONCERNS}

There are several recurring concerns that might temper enthusiasm for this project. Therefore, it is important to unpack them and put them in context, because they are rooted in the rhetoric often used when discussing expanding access to services for people with PLS.

\section{$\underline{5.1 \text { Loss of International Student Fees }}$}

International students are a source of considerable revenue for school boards and PSI in Canada. Accordingly, schools at all levels of education have undertaken significant promotion and recruitment campaigns at the international level to market their programs (Carrasco, 2012; Aberman, 2017). The economic and educational incentives of having international students can therefore not be underestimated, and the possibility of losing the precious revenue international students bring with them will be a contentious topic and significant challenge to overcome.

The argument here is centred around the idea that international students, who realistically have the ability to pay international fees, would somehow "sneak through" as people with PLS. The assumption is that prospective students would opt out of status to qualify for domestic fees. This apprehension not only reflects the lack of understanding about the severe ramifications of being out of or in-between status, but also reflects the long history of associating PLS with possible abuse and fraud. Moreover, given Ryerson's legal autonomy to implement independent policies around admission and tuition fees, safeguards by way of "eligibly criteria" could be put in place to guarantee that this will not the case. 


\section{$\underline{5.2-\text { Floodgates Argument }}$}

Similarly, the floodgates argument is fuelled by the fact that it is impossible to calculate the number of students who would want, or be financially able, to attend university. This situation creates anxiety and misguided fear. The idea that an unmanageably high number of applicants will rush to apply to Ryerson utterly ignores the significant barriers still in place for youth with PLS. Even if a tuition equity policy is put in place, domestic tuition fees might still be too high for youth and deter possible applicants - particularly if one considers that domestic annual tuition for a full-time student at Ryerson university ranges between $\$ 7,000$ - $\$ 11,000$, depending on the program (Tuition and Fess, 2017).

Furthermore, for some the opportunity costs of being in university is too high to undertake. People with PLS in Canada are more likely to have highly precarious jobs and thus low and insecure incomes; and these incomes are often needed for the survival of the entire family unit (Goldring and Landolt, 2013). Accessing PSE could also be hindered by other obligations, such as family obligations, and other limitations imposed by the lack of immigration status.

\section{$\underline{5.3 \text { - Burden on Taxpayers and Denied Opportunities to Residents with Immigration Status }}$}

Increasing accessibility to PSE for people with PLS can come at minimal cost to the public. First, we must acknowledge that throughout their residency in the province of Ontario, people with PLS contribute to public services by way of paying sale and income taxes (F. Villegas, 2014). They also pay property taxes through rent. These significant economic contributions are then used to subsidize provincial and city programs, education and much more (F. Villegas, 2014). Moreover, prospective students will not be attending PSI for free, as they will be required to pay tuition fees and possible government loans if necessary changes to current 
eligibility criteria for OSAP are implemented. Expanding access to PSE might also result in breaking the cycle of poverty that affects this marginalized population. This is an issue that needs to be seriously considered when contemplating the possibility that PSI could become eligible for regularization at some point.

Furthermore, prospective students will be applying under the same academic requirements as other applicants. In some cases, applicants will be competing with equally academic qualified students for admission into Ryerson. In others, they will be at a disadvantage given the additional barriers they face, and in some instances applicants will fill the spaces no one else applied for. Given the small fraction of students, in comparison to the total population at Ryerson, it is misguided to think that students with PLS will be displacing other applicants. Instead, we must consider the significant contributions their experiences will bring to the classrooms and our community, and subsequently to the growth of a highly-skilled labour force and critically educated citizenry in years to come. Therefore, it is important to underscore that this MRP is not advocating for favoritism but rather a tuition equity policy, and to ensure these students are able to succeed at Ryerson University.

\section{4 - Enhancing Accessibility to PSE Rewards "Illegality"}

Opponents of this proposal may also claim that enhancing the accessibility to PSE for people with PLS will reward "illegality" and attract a larger number of PSI to Canada and Ontario to take advantage of this opportunity. However, these arguments, too, are misguided. One clear example is the fact that there has been no documented influx of students with PLS since Ontario recognized the right to education of children and youth regardless of immigration status (Wilson, 2009). People do not migrate solely based on the possibility of accessing 
education; a multiplicity of factors influences the hard decision to leave home, therefore diminishing migration to one reason is ill-founded.

Expanding access would greatly help people with PLS, but their experiences and the risk they will continue to be under cannot be minimized. The aim of this proposal is not to criminalize the tough decision of parents or guardians, who for whatever reason felt it was necessary to immigrate to Canada. Nonetheless, we must recognize that most of the prospective students this MRPS is initially advocating for (i.e. youth with PLS), were minors at their time of entrance into the country. Therefore, they had little say in regard to the decision to immigrate, and, in most cases, were unaware of the circumstances that forced their families to leave. 


\section{CH. 6 - ARGUMENTS ADVOCATING FOR EXPANDED ACCESS}

There are several arguments that could be made regarding expanding access to PSE for people with PLS. This chapter will address some of them to underscore the multiple benefits of this proposal.

\section{$\underline{6.1-\text { Fixed Costs }}$}

Every educational facility has fixed and variable costs of running an institution (Scafidi, 2015). The fixed cost does not change when student enrollment goes up or down and includes general and school administration, operations and maintenance, professors' wages, etc. (Scafidi,

2015). Variable costs, on the other hand, are costs that vary directly with student enrollment. Given the fixed cost of running an undergraduate program, adding a few students to spaces for which no one else had applied, even with a provincial funding shortfall, will not be a complete deficit after all (Aberman, 2017). In fact, in this scenario Ryerson could gain financially from the domestic fees collected from students with PLS, considering that these might be spaces that would have otherwise been empty.

Increasing enrollment for financial gain could be implemented as a long-term solution given its financial appeal for university administrators, since they will be offering only the spaces the university cannot fill otherwise. However, we must also consider the huge equity problem this option will present, as student with PLS will only have limited choices and will need to wait until the last minute to be informed about their acceptances into an undergraduate program. Consequently, this strategy could be a tangible idea for a short-run pilot project, while support 
from other institutions and community members is fostered to advocate for change to provincial and federal policies.

\subsection{Domestic Fees Should be Based on De-Facto Residency}

The initial target group of this project are youth who are living permanently in Ontario and are attending high school in the province. The argument therefore is that given their contributions to our community, they should be entitled to the same provisions as any other residents, especially considering that Toronto -where Ryerson is located - is officially a sanctuary city. Thus, since PLS residents in the city of Toronto technically have access to all city services (TCCC), 2014, Item CD29.11), the next logical step should be to include this population in the expansion of access to PSE and domestic tuition fees schemes. This policy could be implemented in a way that would honor the time and location of residency of this group and later expanded to include access to federal and provincial loans.

Moreover, the eligibility criteria of the tuition equity policy implemented by Queen Mary University of London could serve as a model for a similar strategy at Ryerson University. Otherwise, Ryerson could look to PSI in the USA for some guidance, given the long history of advocacy work relating to expanding access to PSE for undocumented students. The Suggestions for Advocacy Initiatives section of this paper will provide the reader with further details.

\section{$\underline{6.3 \text { Wasted Talent and Lost Opportunity for an Educated Workforce }}$}

PSE plays a key role in a country's development, impacting both individuals and society as whole (Senate Canada, 2011). On average university graduates earned twice the income of those who had not finished high school, and $50 \%$ more than those with college diplomas (Senate 
Canada, 2011). PSE is also associated with an increase in output per capita. The Organisation for Economic Co-operation and Development (OECD) has estimated that each additional year of full-time PSE is associated with an increase in output per capita of about 6\% (Santiago, Tremblay, Basri and Arnal, 2008). Although Canada is considered to have one of the most educated populations in the world, the increase of university graduates over a 10 -year period in the country is lower than the average increase of other OECD countries (OECD, 2010, p.68).

Granting the decrease in university graduates could be explained by the country's high rate to begin with. Nonetheless, the impending retirement of the "baby-boomer" generation makes this trend that much more troublesome. Research indicates that many of the occupations that will be most in demand in years to come rely on educated workers, particularly the senior and managerial positions that will become available after the mass retirement of the "baby boomer" generation (Finnie, Afshar, Bozkurt, Masashi \& Pavlic, 2016). Therefore, in economic terms, expanding access to PSE to people with PLS could help mitigate some of the problems Canada will be facing in the near future. As it stands right now, the initial investment in the compulsory education of this group will pay relatively few economic dividends, as long as they are limited in their ability to continue on to PSE, and subsequently acquire higher paying jobs. A process that would result in better compensated employment, with more tax revenue and greater spending power.

\subsection{Health and Social Benefits of Accessing PSE}

The advantages of having an educated population are not only economic. There are health and social benefits associated with expanding access to education to this group, specifically if we consider that some of these individuals will obtain permanent immigration status in the future. 
Studies have shown that people with more education tend to be in better health, and education seems to have an impact on life satisfaction (Canadian Council on Learning, 2010). It has been estimated that $67 \%$ of Canada's post-secondary graduated considered themselves to be in "very good" or "excellent," health compared with only $43 \%$ of those without a high school diploma (Canadian Council on Learning, 2010). Therefore, the advantages of having an educated population could significantly decrease health-care spending in years to come. Moreover, studies have also shown that individuals with at least some PSE are twice as likely to vote as those with only a high school diploma, and four times as likely to vote as high school dropouts (Canadian Council on Learning, 2010).

For society, increased participation in PSE significantly contributes to socially desirable goals related to social inclusion and community empowerment. Benefits that include reduced welfare dependency, lower crime rates, increased volunteerism, charitable giving and involvement in community organizations. The returns of improving access to PSE are numerous. Nonetheless, the two facts that we must acknowledge: first, these individuals are part of our communities and have, and will, continue to make their lives in Canada with or without permanent immigration status; and second, some of them will become Canadian citizens at some point, and the social, economic and ethical costs of not expanding access to education to them will have to be carried by all of us. 


\section{PART IV \\ WHY RYERSON UNIVERSITY}

\section{CH. 7 - RYERSON'S VISION FOR THE FUTURE AND COMMITMENT TO EDI}

Throughout its history, Ryerson University has been seen as an institution that challenges conventional approaches to PSE (Office of the Provost and Vice President Academic (OPVPA), 2014). It has long prided itself on its innovated thinking, which is rooted in Ryerson's culture and infused in its values (OPVPA, 2014, p.8). In 2014, EDI were identified as priorities in the university's five-year academic plan, Our Time to Lead (OPVPA, 2014, p.10). The plan outlined several strategies that reflect the direction the university envisions for the future. It often referred to the university's geographical location - which is the heart of one of the world's most culturally diverse urban centres - as a source of pride and infinite opportunities (OPVPA, 2014).

Our Time to Lead noted how Ryerson purposefully aims to make PSE more inclusive, in order to have a student population that reflects the increasing diversity of the city (OPVPA, 2014, p.5). The plan also notes that the university understands that its diverse learning community is the drive behind new lines of inquiry, responsive and robust research, innovation, and scholarly and creative endeavours (OPVPA, 2014, p.8); and outlined how crucial it was to make PSE more accessible, in particular for members of under-represented groups, and the importance of challenging conventional ideas of space (OPVPA, 2014, p.8, 2). Our Time to Lead highlights Ryerson's history of blurring the boundaries between its campus and the downtown core (OPVPA, 2014, p.2). This is an idea of crucial importance to this project, given that since 2013 the city of Toronto affirmed itself as a sanctuary city (Toronto City Council and Committees (TCCC), 2014, Item CD29.11). 
If Ryerson University is truly committed to EDI, access, and being one with the City of Toronto, it must show it by investing in all city residents and enacting policies that directly include one of the most marginalized groups. This must be done even if it means taking a financial hit, given that the university will not be receiving provincial transfer credit funding for the students it accepts under this initiative. It is not enough to reaffirm or to proclaim EDI as founding principles. A true commitment requires more than a set of ranking diversity percentages based on specific groups. Rather, it entails the development of integrated strategies that focus on the erosion of barriers and the inclusion of a student population that truly reflects the diversity of the City of Toronto.

Toronto City Council and TDSB policies - even if very limited in scope - align with a growing body of literature that is redefining and deconstructing the concept of membership. Historically, national membership has been defined in relation to a bounded community where the rules of legal citizenship set the parameters of belonging and exclusion (Gonzalez, 2015). New conceptions of membership are challenging the long-standing belief that the nation-state is the sole actor to determine membership and endow rights, and instead calls for the role of communities to do this (Bauder 2012, Carens, 2013, Maas 2013). This work underscores the importance of recognizing the membership of all residents, in a way that supersedes legal citizenship $^{4}$ (Bauder 2012, Carens, 2013, Goldring and Landolt, 2013, Maas 2013). To "treat people politically as 'non-citizens,' that is, as 'stateless,' often signals the first step on the horrorstrewn road to dehumanization" (Oboler, 2009, p.4). This often leads to draconian and punitive

\footnotetext{
${ }^{4}$ In Jama Warsame v. Canada, the UN Human Rights Committee (HRC) noted that membership in a community goes beyond

"country of nationality," and that there are factors other than legal citizenship which may establish close and stronger connections than nationality.
} 
measures that are justified by the label of non-members which has been conceptualized as meaning someone is less-than-human.

Neither city council nor the TDSB or Ryerson have the power to change immigration or citizenship laws. Nevertheless, their roles as gatekeepers do affect the boundaries of the "community" and therefore delineates between those considered to be rightful members and those who are not (P. Villegas, 2014), since membership is negotiated and actively created through everyday practices, and not just through official immigration policies (Menjívar, 2006). Service providers, for example, are responsible, implicitly or explicitly, for maintaining the boundaries of access, and helping structure membership (P. Villegas, 2014).

Ryerson's claim to be a City Builder and being very much a part of its community (OPVPA, 2014, p.5) cannot just be a flashing slogan. This commitment needs to be more than unveiling elaborate construction plans, and investing in the renewal of the downtown core. Being one with the city, and an EDI champion, cannot be a superficial statement, and as community members, we must hold the university accountable for its marketing and claims. Ryerson has a responsibility to all city residents, which includes immigrants with PLS, as it does not operate within a bubble. The university's prominent place in our communities carries a significant level of prestige and power. Its various academic and research partnerships can be leveraged to work alongside other community partners to develop strategies to help immigrants with PLS. These relationships could then be employed to further conceptions of community and aid in the advancement of the university's EDI agenda.

Moreover, if sufficient government and community partnerships are continuously developed, these could be used to reconceptualise the concept of access and thus effectively broaden ideas 
of membership within the community. This process would truly demonstrate Ryerson's city building capacities. Nonetheless, as it has been noted throughout this chapter, here is where Ryerson's history as a trailblazing institution that challenges conventional ideas of space and blurs the boundaries between its campus and the downtown core (OPVPA, 2014, p. 2) come into play. Taking a leadership role on a project like this, would solidify the university's social commitment and responsibility to building an EDI community, while also providing a recognition of the school's place in a larger socio-political structure. Hence, expanding access to PSE for people with PLS is not a request for charity, but rather an acknowledgement that these individuals are valued members of our growing diverse communities. 


\section{PART V \\ SUGGESTIONS FOR LAW AND POLICY REFORM}

\section{CH. 8 - STRATEGIES FOR REGULARIZATION}

As it has been argued throughout this paper, expanding access to PSE to people with PLS is not enough. In order to ensure the successful integration of prospective students into PSE, this project would require the implementation of a tuition equity policy, the expansion of access to financial aid at the provincial and federal level, as well as strong regularization strategies. This last point is paramount considering Gonzales' (2015) twelve-year study, following undocumented young adults in the United States, which highlighted that access to PSE without a strategy for regularization resulted in a narrow range of options and barriers to social and economic mobility for both college and high school graduates.

For some students, being a post-secondary student at a Canadian institution could substantially aid their current processes and present compelling arguments for a Humanitarian \& Compassionate $(\mathrm{H} \& \mathrm{C})$ application. Nonetheless, for others regularization options under existing immigration programs have been exhausted given the narrow eligibility criteria currently in place. Therefore, in light of the absence of sustainable regularization strategies for this group and to ensure a different outcome in the Canadian context, Ryerson University will need to advocate for the expansion and/or creation of new immigration programs that would provide prospective students with regularization options during and after graduation.

\section{$\underline{8.1 \text { Humanitarian \& Compassionate }(\mathrm{H} \& \mathrm{C}) \text { Application }}$}

Applications for permanent residence must, generally, be made from outside Canada, pursuant to s. 9(1) of the IRPA. Nonetheless, pursuant to s.25 of IRPA, foreign nationals in 
Canada have the possibility to request the Ministry of Immigration, Refugees and Citizenship to grant them permanent resident status, or an exception to a provision/obligation under the Act where is justified by humanitarian and compassionate considerations (IRPA, SC 2001, c.27). The $\mathrm{H} \& \mathrm{C}$ decision making process is highly discretionary, and the purpose of this discretion is to provide the Ministry with flexibility to approve "deserving" cases not covered by the legislation (Carrasco, 2012).

The Supreme Court of Canada described the significance of an $\mathrm{H} \& \mathrm{C}$ application in its decision in Baker v. Canada (Ministry of Citizenship and Immigration). The Court acknowledged that though the $\mathrm{H} \& \mathrm{C}$ application provided for an exemption from law, in practice, the application allows for the consideration of external factors when deciding if a refusal to grant the request would more likely than not, result in unusual and disproportionate hardship to the applicant (Baker v. Canada para.15). Therefore, the extent to which a person is established in Canada is part of the inquiry as to whether $\mathrm{H} \& \mathrm{C}$ grounds apply (Guide 5291 - Humanitarian and Compassionate Considerations, 2017).

For youth with PLS, their long residency in the country, cultural and social integration, as well as acceptance and enrollment into PSI could prove extremely beneficial in an $\mathrm{H} \& \mathrm{C}$ application. Nonetheless, the $\mathrm{H} \& \mathrm{C}$ process is lengthy, time-consuming, very expensive and the possibilities of success very uncertain (Carrasco, 2012). Although this group would have the opportunity to apply for a study-permit while their application is ongoing, unless a tuition equity policy is implemented, they will be left with the same financial barriers and insecurities as before the application was made. Moreover, the onus is on the applicant to establish a case for a positive outcome of the $\mathrm{H} \& \mathrm{C}$ application, which more often than not, requires the assistance of a lawyer. 
To assist in the process, Ryerson could initiate partnerships with community centers and legal support groups to ensure prospective students have access to legal support to complete this option.

\subsection{Expansion of the eligibility criteria of current programs}

The federal and provincial government have several programs designed to attract educated immigrants to Canada who will contribute to the country's economic and social development. Nonetheless, the current eligibility criteria for these programs is too narrow and would need to be expanded in order to include youth with PLS. Here advocacy campaigns could be effective to ensure that sustainable pathways for regularization are created. Advocates could pursue the federal government to expand the eligibility criteria of the post-graduation work permit (PGWP) that allows "international students" to work in Canada temporarily after graduation (Stay in Canada After Graduation, 2017). The expansion of PGWP could allow recent graduates to gain valuable employment experience and subsequently gain access to other initiatives such as the Express Entry program.

At the provincial level, campaigns could be launched to advocate for the expansion of Ontario's Provincial Nominee Program (PNP). Provincial programs have greater flexibility and shorter time frames in comparison to federal programs, which makes them attractive alternatives (Carasco, 2012). Persons selected though the PNP do not have to meet the federal selection criteria but are still subjected to the requirement to not be inadmissible as per the provisions of the IRPA (Carasco, 2012). The provincial government could expand its PNP to include academically qualified youth with PLS who have graduated from an Ontario PSI. The expansion

of the PNP would further similar economic and cultural goals of the current programs, while also 
providing consistency with the province's policy on access to education for children and youth regardless of immigration status.

In addition, a campaign advocating for a new permanent resident class for qualified students under this initiative could be launched. A program that accounts for time of residency in the country, educational level, ties to the community, language proficiency among other things. This program could have a similar approach to the one taken by an $\mathrm{H} \& \mathrm{C}$ application, without the lengthy process and preferably better possibilities of success. Nonetheless, efforts to implement similar actions in the United States should be considered in order to avoid the policy flaws of the Deferred Action for Childhood Arrivals (DACA) program, created by then president Obama in 2012 (Wallet, 2015). ${ }^{5}$

${ }^{5}$ DACA grants deferred deportation to immigrants who came to the U.S. under the age of 16, until they turn 31 years (Wallet, 2015). DACA provides successful applicants with employment authorization, a Social Security number and in some states a driver's license (Wallet, 2015). Nonetheless, DACA does not provide legal status, rather a protection that needs to be renewed every two-years (Wallet, 2015). Therefore, although DACA provides legal presence for some individuals it is only prolonging their liminal legality (Menjívar, 2006). Projects like DACA, are problematic because they result in in endowing immigrants with mixed memberships that underscore their complex legal statuses. In addition to the continuation of the program being at jeopardy with new government administrations, which is currently the case under the presidency of Donald Trump. 


\section{CH. 9 SUGGESTIONS FOR A TUITION-EQUITY POLICY AT THE PROVINCIAL}

\section{$\underline{\text { LEVEL }}$}

Realistically, Ryerson and other PSI in the province wanting to undertake this project cannot afford the long-term economic loss of implementing a tuition equity policy without provincial support. Therefore, advocacy efforts should be initially geared at the provincial government requesting the amendment to the criteria used by the MTCU to determine whether a university will receive grant funding for a student's enrollment. This campaign could be modeled after the programs currently in place in the United States at the state level.

\section{DREAM Acts at the state level in the United States}

The United States has a long and complex history in dealing with PLS populations (Najafi, 2008). The size and demographic make-up of the population in the country has proven to be a force to be reckoned with. It has been estimated that people with PLS account for 3.5\%, or over 10 million, of the total population of the United States (Krogstad and Passel, 2015). This has enabled communities to launch large-scale immigrant rights demonstrations over decades that have yielded access to various services, including education (Najafi, 2008). Nonetheless, access to education and other services differs extremely across jurisdictions. The legal structure of the United States is partly responsible for this, but state autonomy has also allowed for initiatives that differed from national policy (Najafi, 2008).

Section 505 of the federal, The Illegal Immigration Reform and Immigrant Responsibility Act, introduced in 1996 sought to prohibit states from providing PSE benefits to "an alien not lawfully present in the United States" (National Conference of State Legislatures (NCSL), 2014). The Development, Relief and Education for Alien Minors Act (the DREAM Act) of 2011, would 
restore the state option to determine residency for the purpose of higher education benefits (NCSL, 2014). Texas became the first state to offer in-state tuition to students with PLS by way of bill HB 1403, California soon followed (AB 540), and a total of twenty states to date offer instate tuition to this group - sixteen by state legislative action and four by state university systems (NCSL, 2014). For students to qualify they must meet a specific criteria which tends to be much stricter than the residency requirements for out-of-state students to gain in-state tuition (Najafi, 2008). For more details on the criteria please see Appendix 6.

The United States provides a robust and detailed example of increased access to PSE for youth with PLS at the state/provincial level, which could inspire similar policies in Ontario. Current tuition equity policies in the U.S acknowledge the importance of accessing higher education and the benefits this provides for the individual and society overall. Moreover, the residency component also recognizes the current and future contributions of youth to society. However, access is inconsistent and fluctuates depending on the jurisdiction in which the student resides.

The funding formula of the U.S. initiative is out of the scope of this paper. Nonetheless, the U.S. experience highlights several important points. First, access to PSE could be achieved if advocacy efforts are organized around the topic. Second, it underscores the unique opportunities in leadership for universities interested in taking up a project like this in Canada, in light of the extensive autonomy of universities and colleges in Ontario to implement their own admissions policies, which greatly differs from the state school system in the USA that enables broadly applied admissions procedures. Therefore, the onus is placed on individual institutions to advocate and implement projects like this one. A strong leader such as Ryerson University could facilitate and coordinate advocacy at multiple PSI. 
Ryerson and its partners will need to advocate for the provincial government to amend the criteria used by the MTCU to determine whether a university will receive grant funding for a student's enrollment. The new eligibility categories could be expanded to include persons who have graduated from a high school in Ontario or meet a quantified residency requirement, which could be like the criteria applied in the US, and the Queen Mary University of London. Changes to this policy could result in the long-term substantiality of this project, allowing PSI in the province the ability to charge youth with PLS domestic tuition rates without losing the provincial subsidy. 


\section{PART VI: SUMMARY OF FINDINGS}

- There are no sanctions or provisions under IRPA or IRPR to penalize institutions that do not enforce the requirement of a student permit and admit people with PLS. Therefore, the conceptualization of this project would only require abstention from Ryerson University.

- PSI are largely autonomous legal bodies pursuant to the Ontario's Post-Secondary Education Choice and Excellence Act 2000, which grants individual acts of incorporation to each institution approved to offer programs leading to a degree. Ryerson University is established and operates under the Ryerson University Act, 1977, which gives the school full responsibility over academic and administrative matters and the authority to set its own tuition fee.

- Mechanisms are already in place that allow people with PLS to apply to PSI in Ontario, all while strictly protecting the sharing of personal information with third parties. Nonetheless, an in-house application process could provide Ryerson with more control over the determination and specific requirements for tuition-equity policies granted to this group and minimize the (potential) risk and anxiety of applicants, in disclosing personal and immigration information to multiple sources.

- Under the current criteria set by the OPFDM, PSIs accepting PLS students would lose the tuition subsidy granted by the provincial government. This would represent a noticeable loss for Ryerson, albeit not an unmanageable one. However, in the future the university could lobby the provincial government to reconsider the eligibility criteria to include this group of students for operating grant purposes. 
- Expanding access to PSE for youth with PLS is critical but insufficient unless a tuition equity policy is implemented. Ryerson University must device a policy that would not only honour youth's continuous residency in the province but would also help alleviate the substantial financial barriers they would face, in light of not being able to access the financial assistance offered under the OSAP, or related to immigration status in Canada. The university could utilize its prominent place in our community to leverage community partners to financially contribute to the education of this group through the creation of special scholarships funded by partnerships between the community and university.

- Taking a leadership role on a project like this, would solidify the university's social commitment and responsibility to building an EDI community by having a student population that truly reflects the diversity of the City of Toronto; while also providing a recognition of the school's place in a larger socio-political structure.

- After the implementation of this project, advocacy efforts by Ryerson, other PSIs and community members should be initially geared in two fronts. First, a strong regularization strategy aimed to lobby the federal and provincial government to expand and/or create new immigration programs that would provide students with tangible regularization options during and after graduation. Second, in light of the long-term economic loss of implementing a tuition equity policy without provincial support, advocacy efforts should be initially geared at the provincial government requesting the amendment to the criteria used by the MTCU to determine whether a university will receive grant funding for a student's enrollment. Both of 
these strategies could be modeled after campaigns and programs currently in place in the United States at the state level. 


\section{PART VII: CONCLUSION}

The efforts at the provincial and local level to ensure the right to primary and secondary education of children and youth regardless of immigration status have created pathways for students with PLS to obtain a high school diploma. Nonetheless, this right is not extended at the post-secondary level, where youth with PLS have only restricted access to PSE. This situation has resulted in a growing pool of high-school educated youth obliged to reshape plans, lower aspirations, who are pushed to the margin of society while friends and classmates with permanent status and citizenship advance through the various stages of life and career. This waste of talent and deferred dreams has devastating emotional and economic consequences on youth with PLS themselves and on Canadian society as a whole.

The aim of this paper was to highlight the paramount urgency of the creation of sustainable pathways to PSE for this population, while at the same time identifying practical ways in which Ryerson and other universities in Ontario can extend access to PSE for youth with PLS. The paper provided a comprehensive overview of regulatory frameworks that govern foreign nationals' access to PSE in Canada, an assessment of procedural and financial barriers, arguments for and against this initiative and suggestions for future policy and legal reforms. Nonetheless, the issues raised in this paper are only initial thoughts and further comprehensive research must be undertaken to ensure students accepted under this initiative are able to succeed throughout PSE, and after graduation.

The future of persons with PLS greatly depends on whether a project like this one is undertaken by supportive universities such as Ryerson, and on legal reforms that ensure persons with PLS have sustainable access to PSE and later regularization programs through which they can put 
their education to use. Advocacy efforts for tuition equity policies and regularization strategies could be modeled after international approaches in an effort to ensure that the policies implemented do not result in further precarity. Given Ryerson's unique commitment to EDI and its intention to be a City Builder, I cannot think of a better leader for this project. 


\section{APPENDIX 1 \\ Eligible criteria for the Ontario Universities Application Centre 1010 \& 105 Undergrad Criteria - Am I a 101 or 105?}

\section{Criteria}

Do you meet all of the following requirements?

- You are taking courses during the day at an Ontario high school (this includes students returning for second semester and graduated students returning to upgrade one or more courses).

- You have not, at some point, been out of high school for more than seven consecutive months.

- You will have received or expect to receive your Ontario Secondary School Diploma (OSSD) with six 4U/M courses at the end of the current year.

- You have not attended a postsecondary institution (college/university/career college).

- You are applying to the first year of an undergraduate degree program or diploma program at an Ontario university.

- You are under 21 years of age.

If yes, you should complete the 101 online application.

\section{Criteria}

Do you meet any of the following requirements?

- You currently reside in Canada (Canadian citizens, permanent residents or those currently studying in Canada on a study permit or other visa), or are a Canadian citizen or a permanent resident living elsewhere (not in Canada), and you are not currently attending an Ontario high school day program.

- You currently reside outside of Canada, and are not a Canadian citizen or permanent resident, and are not currently attending an Ontario high school day program (in Ontario or abroad).

If yes, you should complete the 105 online application. There are two 105 applications $-\underline{105 D}$ for

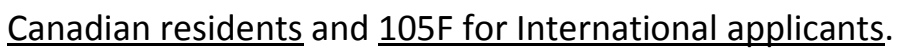




\section{APPENDIX 2}

\section{Screenshot of 105D OSSA application}

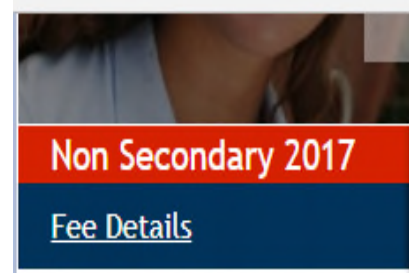

You are logged in as: youthwithPLS Log Out
$\star$ My OUAC Profile
$\star$ My OUAC Financial Account

\section{Application Links}

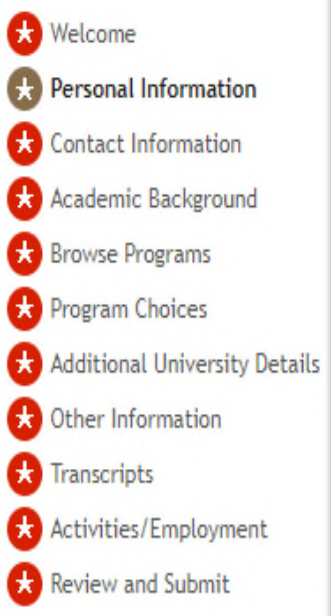

\section{Help Links}

Info
About 105
OuAC \& Privacy
Inticant Responsibilities
Intend to Apply For OSAP?

105 Application " Personal Information

\section{All Other Domestic Undergraduate Applicants (105D)}

\section{Personal Information}

\section{Help}

* Required field

\section{Your Name and Other Personal Information}

Title

Choose v

* First Name (Legal Given Name)

Precarious

Middle Name(s)

? Legal

* Last Name/Family Name

? Status

Preferred/Commonly Used Name

?

Former Last Name/Family Name

?

Gender

Choose v

* Date of Birth (Format: yyyy-mm-dd)

? 1991-11-13

* Status in Canada (at time of applying)

? Canadian Citizen

Permanent Resident

Study Permit

Diplomatic

Convention Refugee (Protected Person)

Visitor

No Status

* Country of Citizenship

Choose v




\section{APPENDIX 3}

\section{Eligibility for the Ontario Student Assistance Program}

Step 1. Check your eligibility

If you plan to apply for the Ontario Student Assistance Program (OSAP) you must be eligible to apply but you must also be aware of situations which may affect your eligibility. Please review the information below.

\section{$\underline{\text { OSAP eligibility for degree students }}$}

To apply for full-time OSAP aid, you must:

- register in full-time studies for the session (see also: calculating course load).

- be a Canadian citizen, permanent resident or have protected person status; international students are ineligible.

- have Ontario residency, that is, have lived in Ontario for at least 12 consecutive months without attending full-time postsecondary school.

- register in an OSAP-approved degree program. Most degree programs at York are OSAP approved.

- be neither in default on a previous OSAP student loan nor on OSAP restriction.

- maintain satisfactory academic progress while receiving OSAP aid.

- have demonstrated financial need as calculated by the government. Gross family income as well as student resources and assets are taken into consideration.

\section{Calculating course load}

Course load refers to the number of registered course credits for a session.

For undergraduate students without a permanent disability, a 100 per cent course load in the Fall/Winter session is $\mathbf{1 5}$ credits in each term. Note: This is not necessarily equivalent to registering for 30 credits in the Fall/Winter session, unless exactly half of your registered credits are in each term

\section{$\underline{\text { Factors that may affect OSAP eligibility and aid }}$}

The following may affect your OSAP eligibility and aid:

- Dropping courses.

- Dropping to part-time status during the year.

- Withdrawing from your program.

- Increases in your income, awards or other resources.

- Reporting incorrect income information (student, parents or spouse) on your original application.

- Receiving more OSAP aid than you were entitled to in two academic years.

- Failing courses. 


\section{APPENDIX 4}

\section{Eligibility criteria for Provincial Educational Transfers}

\subsection{ELIGIBLE STUDENTS}

A student is eligible to be counted for operating grants if that student:

a) is enrolled at an eligible institution (see Section 2); and

b) is enrolled in a publicly-supported program (see Section 3); and

c) is enrolled in a program that meets the specific eligibility criteria for undergraduate courses/units of

study discussed in Section 4.4 (only applicable to undergraduate students); or

d) meets the eligibility criteria for graduate students discussed in Section 4.5

(only applicable to

graduate students) and falls into any of the categories outlined below:

\subsubsection{Citizens}

A citizen of Canada within the meaning of the Citizenship Act, or a person registered as an Indian within the meaning of the Indian Act.

\subsubsection{Permanent Residents}

A permanent resident within the meaning of the Immigration and Refugee Protection Act:

a) a person who has been granted "permanent resident" status and has not had that status revoked;

or

b) a person who has been approved "in-principle" for permanent resident status in Canada. Evidence of this is a letter which confirms that Citizenship and Immigration Canada has determined that he/she is eligible for immigration to Canada or meets the eligibility requirements to apply for permanent resident status in Canada. Such letters must be dated prior to the enrolment count date and presented prior to the enrolment report due date. Please see Appendix 5 for examples of accepted letters

4.1.3. Eligible International Students

The status of all international students who are eligible to be counted for operating grant purposes must be fully documented and valid during the academic period for which they are being counted.

An international student is eligible to be counted for operating grant purposes if that student falls within any of the following categories:

a) A person who is the dependent (see Section 1.1.7 for definition) of a Canadian citizen or permanent resident of Canada.

b) A visitor, and his/her dependents (see Section 1.1.7 for definition), who is authorized to work in Canada having been issued a work permit. The following students are excluded from this category:

i. A visitor who is a graduate teaching assistant;

ii. An international student holding a work permit to complete his/her co-op, internship or medical residency employment; 
iii. An international student holding an open work permit for postgraduate work (usually for up to three years of work opportunities upon graduation);

iv. An international student whose spouse or common-law partner has received a work permit as a result of the international student holding a valid Study Permit;

v. An international student holding an "Off-Campus Work Permit". c) A visitor who is admitted to and remaining in Canada with official accreditation from the Canadian Department of Foreign Affairs and International Trade, who has entered Canada, or is in Canada, to carry out her/his official duties as:

\subsubsection{Protected Persons}

i. a diplomatic or consular officer;

ii. or as a Canadian government-accredited representative or official of a country other than Canada, of the United Nations or any of its agencies, of any intergovernmental organizations of which Canada is a member; iii. or as a dependent (see Section 1.1.7 for definition) or a member of the staff of any such diplomat, consular officer; representative or official accredited to Canada by the Canadian government;

iv. or a member of a foreign military force or of a civilian component; thereof admitted to Canada under the Visiting Forces Act or any dependents of such personnel.

A person, and his/her dependents, who:

a) has been determined to be a protected person, including a Convention refugee or a person in need of protection, within the meaning of subsection 95(2) of the Immigration and Refugee Protection Act by the Immigration and Refugee Board (IRB) or the Minister of Citizenship and Immigration Canada. A protected person document issued under section 31(1) of the Immigration and Refugee Protection Act or a "notice of decision" issued by the Minister of Citizenship and Immigration Canada or by the IRB must be presented.

b) is a refugee claimant who applied to the federal government for Convention refugee status prior to January 1, 1989, and can provide documentation from Citizenship and Immigration Canada to that effect. 


\section{APPENDIX 5}

\section{The Queen Mary University of London's eligibility criteria for the Asylum Seekers Bursary}

\section{Eligibility}

To be considered for an asylum seekers fee concession, you must meet the following requirements:

- you or your parent/guardian or spouse/partner must have submitted an asylum or human rights application, which is awaiting a decision from the Home Office;

- have applied for asylum before applying to study at university;

- hold a conditional or unconditional offer to study at Queen Mary University of London in the following academic year AND accepted this firmly;

○ not have completed undergraduate degree level study elsewhere.

Terms and Conditions

Fee concessions will be awarded automatically to students who enrol at Queen Mary University of London, subject to the following terms and conditions.

1. You must meet the general eligibility criteria set out above.

2. You must be holding a conditional or unconditional offer of a place on an undergraduate programme, except those courses offered by the School of Medicine and Dentistry that lead to qualified status as a doctor, dentist or dental hygienist or therapist.

3. You must have accepted your offer from Queen Mary University of London as your firm choice.

4. The award will remain in place while your asylum application is under consideration by the Home Office. During this period your fee status will be recorded as 'overseas' but you will be required only to pay the 'home' rate of tuition fee. If or when your asylum application is successful and you are granted refugee status, your fee status will be changed to 'home'.

5. The award will be provided in each standard year of study for the course to which you are admitted. Extension of the award to cover repeat years of study or additional years resulting from a change of programme, e.g. from three to four years, will be approved on a discretionary basis only.

6. You will be required to provide evidence of your immigration status annually in advance of enrolment in September. We reserve the right to verify your immigration status with the Home Office.

7. Awards are discretionary and we reserve the right to withdraw awards if we receive information from the Home Office that you should not be studying in the UK. 


\section{APPENDIX 6}

\section{State's eligibly criterial for in-state tuition fees in the United States}

- Must have successfully graduated or obtained a General Education Diploma (GED)

- Must be accepted to an accredited institution in the state

- Have two to three years of residence in the state

- Student is required to sign an affidavit stating that they have filed/will file an application for regularization as soon as possible

(NCSL, 2014) 


\section{REFERENCES}

\#RefugeesWelcome: QMUL Activity In Support of Refugees. (2017). Queen Mary University of London. Retrieved from http://www.qmul.ac.uk/refugees-welcome/.

Assembly, U. G. (1966). International covenant on economic, social and cultural rights. United Nations, treaty series, 993(3).

Aberman, T. (2017). Conversation regarding expanding access to PSE for youth with PLS. [in person unrecorded meeting].

Applications and Related Forms. (2017) Ryerson University. Retrieved from http://www.ryerson.ca/admissions/undergraduate/applications-related-forms/

Article 26. (2017). The Helena Kennedy Foundation. Retrieved from http://www.hkf.org.uk/article-26-awards-1.

Asylum Seekers Fee Concession. (2017). Queen Mary University of London. Retrieved from http://www.qmul.ac.uk/undergraduate/feesandfunding/bursaries/asylum-seekersupport/173232.html.

Babbage, M. (2008, June 11). Ontario schools shouldn't pick and choose with illegal immigrant kids: McGuinty. The Canadian Press.

Baker v. Canada (Minister of Citizenship and Immigration), [1999] 2 S.C.R. 817

Bauder, H. (2012). Immigration and settlement: Challenges, experiences, and opportunities. Canadian Scholars' Press.

Bernhard, J. K., Goldring, L., Young, J., Berinstein, C., \& Wilson, B. (2007). Living with precarious legal status in Canada: Implications for the well-being of children and families. Refuge: Canada's Journal on Refugees, 24(2).

Bowen, G. A. (2009). Document analysis as a qualitative research method. Qualitative research journal, 9(2), 27-40.

Canadian Council on Learning (2010). 2009-2010 State of Learning in Canada: A Year in Review, 30 March 2010. Retrieved from http://www.ccl-cca.ca/pdfs/SOLR/2010/SOLR-2010Report-FINAL-E.pdf

Carens, J. (2013). The ethics of immigration. Oxford University Press.

Carasco, E. F. (2007). Constitutional, administrative and international review. Immigration and refugee law: Cases, materials and commentary. Emond Montgomery Publications, 139-215 
Carasco, E. F. (2007). Temporary Residents. Immigration and refugee law: Cases, materials and commentary. Emond Montgomery Publications, 231-288.

Constitution Act, 1867 (UK), 30 \& 31 Vict., c.3. reprinted in RSC 1985, app. II, no.5

Education Act, R.S.O. 1990, c. E.2.

Education (Fees and Awards) (England) Regulations (EFAER). (2007). The Legislative Branch of the UK Government. Retrieved from http://www.legislation.gov.uk/uksi/2007/779/contents/made.

Eisner, E. W. (1991). The enlightened eye: Qualitative inquiry and the enhancement of educational practice. Toronto: Collier Macmillan Canada

Finnie, R., Afshar, K., Bozkurt, E., Masashi, M., \& Pavlic, D. (2016). Barista or Better? New Evidence on the Earnings of Post-Secondary Education Graduates: A Tax Linkage Approach. Education Policy Research Initiative, University of Ottawa, 1-75. Retrieved 3 Feb. 2017, from https://static1.squarespace.com/static/5557eaf0e4b0384b6c9b0172/t/57a3595eb8a79b06bc68 6cbf/1470323048183/EPRI-ESDC+Tax+linkage_Report.pdf.

Freedom of Information and Protection of Privacy Act, R.S.O. 1990, c. F. 31.

General Motors of Canada Ltd. v. City National Leasing, [1989] 1 S.C.R. 641

Goldring, L., \& Landolt, P. (2013). Producing and negotiating non-citizenship: Precarious legal status in Canada. University of Toronto Press.

Goldring, L., Berinstein, C., \& Bernhard, J.K. (2009). Institutionalizing precarious migratory status in Canada. Citizenship studies 13(3), 239-265.

Gonzales, R. G. (2015). Lives in limbo: Undocumented and coming of age in America. University of California Press.

Guide 5291 - Humanitarian and Compassionate Considerations. (2017). Government of Canada. Retrieved from http://www.cic.gc.ca/english/information/applications/handc.asp

Hodge v The Queen: PC 15 Dec 1883

Hogg, P. (2007). Constitutional Law of Canada, $5^{\text {th }}$ Ed. Vol.2. Toronto: Carswell.

Hudson, H., Atak, I., Manocchi, M., Hannan, C. (2017). (No) Access T.O.: a pilot study on sanctuary city policy in Toronto, Canada. Ryerson Centre for Immigration \& Settlement. 1-39. Retrieved from http://www.ryerson.ca/content/dam/rcis/documents/RCIS\%20Working\%20Paper\%202017_1 GHudsonFinal\%20.pdf

Immigration and Refugee Protection Regulations, S.O.R./2002-227 [the IRPR]. 
Immigration and Refugee Protection Act, SC 2001, c.27 [the IRPA].

Kirby, D. (2007). Reviewing Canadian Post-Secondary Education: Post-Secondary Education Policy in Post-Industrial Canada. Canadian Journal of Educational Administration and Policy, 65, 1-24.

Lachemi, M. (2016). Ryerson university president and vice-chancellor Mohamed Lachemi installation address September 30, 2016. Retrieved from http://www.ryerson.ca/content/dam/about/president/documents/President\%20Lachemi\%20Ins tallation\%20Speech_Sept\%2030.pdf

Lynch, L. (2017, July 7). 'Impossible to close the gap': Immigration board boss says more resources needed to process legacy refugees. CBCNews, Canada. Retrieved from http://www.cbc.ca/news/canada/legacy-refugees-resources-dion-1.4191984d

Maas, W. (Ed.). (2013). Multilevel citizenship. University of Pennsylvania Press.

Macdonald, D., Shaker, E. (2014). Tier for two: managing the optics of provincial tuition fee policies. Canadian Centre for Policy Alternatives. 1-32.

Menjívar, C. (2006). Liminal Legality: Salvadoran and Guatemalan Immigrants' Lives in the United States 1. American journal of sociology, 111(4), 999-1037.

Multiple Access Ltd. v. McCutcheon, [1982] 2 S.C.R. 161

National Conference of State Legislatures (NCSL). (2014). In-State Tuition and Unauthorized Immigrant Students. Retrieved from http://www.ncsl.org/research/immigration/in-state-tuitionand-unauthorized-immigrants.aspx.

Neuman, W. L. (2016). Understanding research. Pearson.

Organization for Economic Co-operation and Development (OECD). (2010). OECD indicators, Education at a Glance 2010. Retrieved from http://www.oecd.org/dataoecd/45/39/45926093.pdf

Office of the Provost and Vice President Academic. (2014). Our Time to Lead: Academic Plan 2014-2019. Ryerson University. Retrieved from http://www.ryerson.ca/content/dam/provost/PDFs/RU_Academic\%20Plan_2014_PrintFriendl y.pdf

Ontario Education Number (OEN). (2017). Information for Parents and Students. Ontario Ministry of Education. Retrieved from http://www.edu.gov.on.ca/eng/document/brochure/oen/

Ontario Operating Funds Distribution Manual (OPFDM). (2010). A Manual Governing the Distribution of Ontario Government Operating Grants to Ontario Universities and 
University-Related Institutions (Formula Manual). Retrieved from

http://docplayer.net/5355825-The-ontario-operating-funds-distribution-manual.html

Post-Secondary Education Choice and Excellence Act, 2000, S.O. 2000, c. 36, Sch

Refugees Into Teaching. (2013). Fees and Funding. Retrieved from https://www.refugeecouncil.org.uk/assets/0003/0177/Fees_and_funding.pdf.

Rumbaut, R. G. (2004). Ages, life stages, and generational cohorts: Decomposing the immigrant first and second generations in the United States. International migration review, 38(3), 11601205.

Russell, P. H., Knopff, R., Bateman, T. M., \& Hiebert, J. (2008). The Court and the Constitution: Leading Cases.

Ryerson University Act, 1977 S.O., 1997 c.47. Retrieved 15 Jan. 2017, from http://www.ryerson.ca/content/dam/senate/ryersonact.pdf.

Santiago, P., Tremblay, K., Basri, E., \& Arnal, E. (2008). Tertiary education for the knowledge society (Vol. 1). Paris: OECD.

Scafidi, B. (2015). Will School Choice Lead to Fewer Resources for Students Who Remain in Public Schools? Education Choice. https://www.edchoice.org/blog/will-school-choice-leadto-fewer-resources-for-students-who-remain-in-public-schools/

Senate Canada. (2011). Opening the door: reducing barriers to post-secondary education in Canada. Standing Senate Committee on Social Affairs Science and Technology. 1-130. Retrieved from https://sencanada.ca/content/sen/committee/411/soci/rep/rep06dec11-e.pdf

Slobodian, L., Kits, H. (2013). Student Loans for Refugees: A Success Story for Policy Change. Caledon Institute of Social Policy. Retrieved from http://www.caledoninst.org/Publications/PDF/553820711.pdf

Stake, R. E. (2013). Multiple case study analysis. Guilford Press.

Statistics Canada. (2009). Education Indicators in Canada: An International Perspective, Ottawa

Stay in Canada After Graduation. (2017). Government of Canada. Retrieved from http://www.cic.gc.ca/english/study/work-postgrad.asp

The Constitution Act, 1867 (UK), 30 \& 31 Vict., c.3. reprinted in RSC 1985, app. II, no.5

The International Comparative Higher Education and Finance Project. (2010). Higher Education Finance and Cost-Sharing in Canada. 1-6. Buffalo. Retrieved from https://scholar.google.ca/scholar?hl=en\&q=http $\% 3 \mathrm{~A} \% 2 \mathrm{~F} \% 2 \mathrm{Fgse}$. buffalo.edu\%2Forg\%2Finth 
igheredfinance\%2Ffiles\%2FCountry_Profiles\%2FNorth_America\%2FCanada.pdf\&btnG=\&a s_sdt $=1 \% 2 C 5 \&$ as_sdtp

The Toronto Star. (2017, July 10). “Don't leave them behind.” Toronto Star [Toronto, Ontario], p. A10. Retrieved from Canadian Periodicals Index Quarterly, <go.galegroup.come/ps/i.do?p=CPI\&sw=w\&u=rpu_main\&v=2.1\&id=GALE\%7CA49813092 $1 \& \mathrm{it}=\mathrm{r} \& \mathrm{asid}=9 \mathrm{~b} 843621721 \mathrm{aa} 3513 \mathrm{e} 11628 \mathrm{f} 41 \mathrm{e} 8 \mathrm{c} 01>$

Toronto City Council and Committees (TCCC). (2014). City Council Minutes: Item CD29.11. Access to City Services for Undocumented Torontonians. Retrieved April 1, 2017, from http://app.toronto.ca/tmmis/viewPublishedReport.do?function=getCouncilMinutesReport\&me etingId=7853.

Toronto District School Board (TDSB). (2007). Summary of decisions regular meeting May 16, 2007. Retrieved from http://www.tdsb.on.ca/wwwdocuments/students/pathways_for_success/docs/70516\%20s umm.pdf on March 29, 2017

Tuition and Fees. (2017). Ryerson University. Retrieved from http://www.ryerson.ca/admissions/tuition-fees/

Young, J. (2013). "This is my life:” Youth negotiating legality and belonging in Toronto. In L. Goldring \& P. Landolt (Eds.), Producing and negotiating non-citizenship: Precarious legal status in Canada. (99-117). Toronto: University of Toronto Press.

Villegas, F. (2013). Getting the "don't ask don't tell" at the Toronto district school board: mapping the competing discourses of rights and membership. In L. Goldring \& P. Landolt (Eds.), Producing and negotiating non-citizenship: Precarious legal status in Canada, 258273. Toronto: University of Toronto Press.

Villegas, F. (2014). The Politics of "Access": Undocumented Students and Enrollment in Toronto Schools (Doctoral dissertation, University of Toronto).

Villegas, P. (2013). Negotiating the boundaries of membership: health care providers, access to social goods, and immigration status. In L. Goldring \& P. Landolt (Eds.), Producing and negotiating non-citizenship: Precarious legal status in Canada, 221-239. Toronto: University of Toronto Press.

Wallet, N. (2015). 5 facts you need to know about the DREAM Act. USA Today College. Retrieved from http://college.usatoday.com/2015/02/26/5-facts-you-need-to-know-about-thedream-act/

Wilson. M. (2009). Access to postsecondary education for undocumented immigrants. [unpublished]. Parkdale Community Legal Services, 1-59, Toronto: Ontario. 